\title{
PARA LA GÉNESIS DE LOS COMENTARIOS REALES EDICIÓN Y COMENTARIO DE LAS APOSTILLAS DEL INCA GARCILASO (Y OTROS) A LA HISTORIA GENERAL DE LAS INDIAS DE F. LÓPEZ DE GÓMARA
}

Fue el historiador R. Porras Barrenechea quien a fines de los años cuarenta dio la primicia, en una serie de tres artículos publicados en El Comercio de Lima, de haber salido a la luz un ejemplar de la obra mencionada en el título, el cual contenía numerosas anotaciones autógrafas del Inca Garcilaso y de otro personaje contemporáneo del insigne escritor ${ }^{1}$. A raíz de los artículos de Porras Barrenechea el ejemplar en cuestión -hoy en la Biblioteca Nacional del Perú2 ${ }^{2}$-fue reconocido por los garcilasistas como una verdadera "joya", no sólo por su valor anticuario, sino por ser pieza clave para entender un período importante de la formación intelectual del escritor y, particularmente, los antecedentes y la génesis de su obra historiográfica.

El ensayo de Porras Barrenechea se reeditó más de una vez en forma unitaria ${ }^{3}$ y durante mucho tiempo constituyó la fuente de información fundamental sobre el ejemplar de Gómara

1 "Una joya bibliográfica peruana”, El Comercio, Lima, 15, 16 y 17 de septiembre de 1948, pp. 3, 3-4 y 3-4, respectivamente. En este ensayo se exponen también las cuestiones relativas a la aparición del ejemplar.

${ }^{2}$ Se trata de un ejemplar de la edición de Zaragoza, impresa por Pedro Bernuz en 1554 (como se indica en el colofón), pero el pie de imprenta es de 1555 . Mide $29.5 \times 25.5 \mathrm{~cm}$ y la encuadernación es de época posterior. La portada en dos tintas, negra y roja, está adornada por un escudo con las águilas imperiales. El libro tiene iniciales miniadas en los capítulos y numerosas ilustraciones. En general, está bien conservado, pero el refilado de los márgenes ha hecho que se pierda parte de numerosas apostillas.

${ }^{3}$ La última de las reediciones, hasta donde sé, es la que se encuentra en R. Porras Barrenechea, Los cronistas del Perú, ed. F. Pease G. Y., Banco de Crédito del Perú, Lima, 1986, pp. 753-767. Todas las referencias a Porras Barrenechea, con el nombre o con la sigla $P B$, remiten a esta edición. 
apostillado en el siglo $\mathrm{XvI}^{4}$, el cual, si bien dio lugar a numerosas referencias y a algunos comentarios, entre los que destacan los de A. Miró Quesada ${ }^{5}$, no ha merecido un nuevo y necesario análisis que permita corregir y evaluar las lecturas ofrecidas por Porras Barrenechea en su benemérito esfuerzo inicial, así como las hipótesis derivadas de aquéllas ${ }^{6}$. Sólo hay que recordar, en este contexto, que el ejemplar apostillado ha sido materia, hace unos años, de una edición facsimilar ${ }^{7}$, la cual, si bien no constituye una reproducción fiel y auténtica en todos los detalles $^{8}$, permite obtener una imagen aproximada del origi-

${ }^{4} \mathrm{El}$ hecho de que el escrito de Porras Barrenechea no se haya publicado fuera del ámbito peruano quizá explique la desinformación de F. G. Crowley, quien en su estudio sobre las fuentes de los Comentarios (Garcilaso de la Vega el Inca and his sources in "Comentarios Reales de los Incas", Mouton, The Hague, 1971) ignora la existencia de este ejemplar, del cual cita Garcilaso, y se esfuerce por encontrar las razones (cap. 3) por las cuales las indicaciones de capítulos que da el Inca no corresponden a la edición de 1552 (la edición del ejemplar apostillado es la cuarta, de 1554-1555).

5 Véase "La biografía de Gonzalo Silvestre. A propósito de las anotaciones manuscritas en un ejemplar de la Historia de Gómara", en Memoria del Director de la Biblioteca Nacional, 1953-1954, pp. 76-80. Y cf., ahora, como versión última de la ocupación garcilasista de este insigne estudioso, El Inca Garcilaso, Pontificia Universidad Católica del Perú, Lima, 1994 (las apostillas se tratan en las pp. 229-233).

${ }^{6}$ Porras Barrenechea leyó, de modo solvente, una parte de las apostillas, con reconstrucciones en general atinadas y basadas en las fuentes. La transcripción, sin embargo, deja que desear, no sólo por la modernización de la ortografía. A Porras Barrenechea se debe, por lo demás, la identificación del "conquistador", mencionado por Garcilaso a propósito de algunas apostillas, con Gonzalo Silvestre. Asimismo, intentó la atribución de autoría de las apostillas. En los lugares correspondientes mencionaremos sus opiniones al respecto.

${ }^{7}$ Francisco López de Gómara, Historia general de las Indias, ed. facs., Comisión Nacional del Quinto Centenario del Descubrimiento de AméricaEncuentro de Dos Mundos, Lima, 1993.

${ }^{8}$ La reproducción fotográfica de numerosas apostillas fue retocada, repasándose el trazo gráfico y añadiéndose letras (e inclusive palabras) faltantes por el deterioro del ejemplar. Esto explica que, en la edición que ofrecemos aquí, haya abundantes casos de letras que reconstruimos entre corchetes, las cuales aparecen en la edición facsimilar como si se hubiesen conservado en el original. En las páginas finales (sin numerar) de la edición hay un intento, muy defectuoso, de transcripción y reconstrucción, que no aprovecha los esfuerzos anteriores ni se apoya en las fuentes garcilasianas. Como no vale la pena detenerse en comentar cada caso, nos limitamos a algunas referencias que han parecido oportunas en los lugares específicos. 
nal y, por consiguiente, contextualizar gráficamente las apostillas respecto del texto apostillado.

El presente trabajo constituye una edición de las apostillas que se encuentran en el mencionado ejemplar de la Historia general de las Indias de López de Gómara9 ${ }^{9}$. El objetivo ha sido, en primer lugar, ofrecer una transcripción lo más ajustada posible, con criterio paleográfico, de los textos conservados, reconstruyéndolos, allí donde fuese necesario, sobre la base de las fuentes garcilasianas o según el propio ingenio. Como todo ello se hace de modo transparente, el lector tendrá la posibilidad de aceptar las propuestas de lectura y las conjeturas del editor, o de disociarse de ellas. En segundo lugar, me he propuesto no sólo transcribir y reconstruir las apostillas, sino comentarlas, contextualizándolas -siempre que ha sido posible- en la obra del Inca.

Cada una de las apostillas que se edita aparece numerada (aunque, en algunos casos, y por las razones que se verán en su lugar, he reunido bajo un mismo número más de una). Indico primero el folio, el capítulo y el margen en los que se encuentra. Luego viene el texto de la apostilla y, finalmente, un comentario: en éste ofrezco, cuando es el caso, información sobre la propuesta de lectura y de reconstrucción, señalo los lugares de la obra del Inca que corresponden temática o literalmente a la apostilla, y me refiero también al modo en el que ésta se integra en el discurso historiográfico de nuestro autor. Naturalmente, no siempre es posible abundar en consideraciones de este tipo. Por lo demás, la edición en secuencia deja fuera varias apostillas que consisten solamente en la repetición de una fecha, una cifra, un nombre, dados por Gómara, y que me han parecido menos importantes que las editadas; de ellas trato globalmente al final, junto con otras marcas de lectura, como los abundantes subrayados.

Uno de los problemas más complejos, no de la edición, pero sí de la evaluación de las apostillas, es el de cuáles son de Garcilaso y cuáles de otra mano. El Inca mismo, en dos lugares de la Historia general del Perú, se refiere al ejemplar de la Historia de Gómara que vio "marginado de su mano" por un "con-

${ }^{9}$ Algunos avances fueron publicados en "El taller del Inca Garcilaso. Sobre las anotaciones manuscritas en la Historia general de las Indias de F. López de Gómara y su importancia en la composición de los Comentarios Reales", RFE, 75 (1995), 57-84. 
quistador del Perú", el cual ha sido identificado con el mismo que le sirvió de fuente oral para la redacción de La Florida, a saber, Gonzalo Silvestre ${ }^{10}$. Tal declaración aparece convalidada por el ejemplar conservado, en el cual Garcilaso identifica en tal sentido las dos anotaciones aludidas (cf. 16 y 55: Comentario). En otras dos ocasiones, en el ejemplar de Gómara que analizamos, se atribuyen las apostillas al "conquistador" (cf. 20 y 22). A pesar de que estas dos últimas declaraciones identificadoras no aparecen firmadas, y de que las correspondientes apostillas de Silvestre no están mencionadas en textos del Inca (a diferencia de lo que ocurre con las dos señaladas en primer lugar), no cabe ninguna duda, tanto por la letra cuanto por la formulación análoga, de que son de Garcilaso. Además de estos casos unívocos, hay otros bastante claros, por la semejanza que presentan con los primeros. En lo que respecta a Silvestre, también las similitudes gráficas hablan a veces por sí mismas. De cualquier modo, el único criterio válido para asignar una apostilla a una mano o a otra consiste en partir, como punto de referencia, de los casos unívocos.

La escritura de Garcilaso en las apostillas que sin duda le pertenecen se singulariza por unas letras claras y cuidadas, separadas entre sí, sin enlaces y de trazo vertical. En cambio, la del conquistador es más bien descuidada, con letras cursivas algo gruesas. Pero fuera de los casos unívocos, hay numerosas apostillas que presentan un tipo de escritura que no es idéntica a las descritas. Además, algunas otras muestras manuscritas del Inca hacen ver que éste no escribía sólo con el trazo mencionado, sino que usaba también una letra cursiva con algunos enlaces ${ }^{11}$. Se impone, por consiguiente, una gran prudencia en la asignación de las apostillas gráficamente ambiguas a un deter-

${ }^{10}$ Este personaje estuvo en el Perú después de la expedición a La Florida, en la que participó. Su condición de informante para la obra del Inca sobre esta expedición fue señalada por J. DE LA RIva-AgÜERo y OSMA, La historia en el Perú, Lima, 1910, p. 43. Porras Barrenechea (cf. supra, nota 6) lo identificó como el "conquistador" mencionado por Garcilaso. Silvestre aparece nombrado muchas veces en la Historia general del Perú, sea como protagonista de ciertos lances, sea como informante.

11 Son autógrafos del Inca la Relación de la descendencia de Garci Pérez de Vargas [1596; hay rep. facs. publicada en Lima, Universidad Nacional Mayor de San Marcos, 1951] y las cartas descubiertas por E. AsEnsio, "Dos cartas desconocidas del Inca Garcilaso", NRFH, 7 (1953), 583-593. Lo que digo arriba remite a algunas partes de la Relación..., tal como se muestra en la reproducción mencionada (pp. 30-32). 
minado redactor, restringiendo al máximo la validez de los criterios "psicológicos" o "morales", que pueden ser engañosos y llevar a círculos viciosos ${ }^{12}$. Más confiables son los criterios lingüísticos o estilísticos. Hay algunas apostillas de redacción torpe, como aquella sobre la expedición de Almagro a Chile, la cual, para ser citada por Garcilaso en la Historia general del Perú, debió pasar por una corrección severa, que la hiciera compatible estilísticamente con el contexto en el que debía aparecer (cf. 55). Difícilmente se pueden atribuir a Garcilaso otras apostillas también de redacción defectuosa, pues es palmario el cuidado que pone el Inca al respecto, notorio inclusive en apostillas bastante deturpadas (cf., por ejemplo, 38). Algo similar puede decirse de la ortografía: Garcilaso es seguidor de la norma ortográfica culta de la época, cuidadoso, por ejemplo, en el uso de la ese doble ${ }^{13}$, que, en cambio, el conquistador no respeta, y que Garcilaso corrige cuando transvasa a la Historia general del Perú el relato de la expedición a Chile. También la escritura de los nombres indígenas puede ser un criterio. Es verdad que Garcilaso en estas apostillas vacila, aparte Peru y Piru, entre inca e inga, a pesar de lo cual es probable, y no sólo por la letra, que las graficaciones usuta (28), [H] uaynacapac (33), Manco Ynca $(40,78)$, Cassamarca $(41)$, paullu $(50)^{14}$, provengan de él, mientras que Atabalipa (29) o saire topa ynga (31) sean de Silvestre.

12 Porras Barrenechea señala, por ejemplo, que en los casos de "anotaciones breves y rápidas en que es difícil precisar al autor... hay que optar, para decidirse, por las características morales o estilísticas de los personajes" (p. 758). Pero el criterio "moral" parte de un ideal de carácter del personaje y no tiene en cuenta las eventuales diferencias que pueden darse a lo largo de los años en la escritura de una persona, o aquellas otras debidas al mayor o menor cuidado que se ponga, o inclusive a la naturaleza de lo que se escribe. No se puede negar, sin embargo, que los rasgos de personalidad de Silvestre y de Garcilaso parecen haber sido bastante diversos.

13 Así, por ejemplo, en las cartas publicadas por Asensio (art. cit.), no hay errores en el uso de "s" y "ss" (no considero error "ss" en desseo, pues esta grafía no etimológica estuvo bastante difundida y se encuentra inclusive en Nebrija), salvo un caso de ceso y otro de bessando, respecto de los cuales podría pensarse en un trueque involuntario debido a la contigüidad de las dos palabras ("ceso bessando": la fidelidad de la transcripción de Asensio se comprueba en el fragmento facsimilar de una de las cartas publicado en la ed. de $C R$ de C. Pacheco Vélez, Lima, 1985, entre las pp. 314-315). Tampoco hay faltas en el uso de "sc". De modo general, y sin entrar ahora en el detalle, vale lo mismo para la Relación de la descendencia... (cf. supra, nota 11).

${ }^{14}$ En efecto, se trata de graficaciones más respetuosas de la lengua indígena, o por lo menos que el Inca consideraba tales. En verdad, el rechazo 
En este punto cabe añadir que no hay razón suficiente para establecer que las apostillas procedan de sólo dos manos. Si bien ésta ha sido hasta ahora la interpretación casi unánimemente aceptada, creo que puede haber fundamento para dudarlo, por lo menos en un caso: en efecto, hay una apostilla (5) que suscita una segunda (en mi opinión, de letra de Garcilaso), la cual atribuye la primera a "un platero". De modo que, junto a cuatro casos de apostillas identificadas como del conquistador, hay este otro que sugiere una diferente adjudicación (cf. el Comentario). Es evidente que no se puede excluir que otra u otras apostillas no identificadas explícitamente respecto de su autoría fueran de mano diversa.

El ejemplar de Gómara parece haber pertenecido a Silvestre, quien lo marginó "de su mano", como dice el Inca. Dada la antigua relación amistosa que vinculaba a ambos personajes y las veces que se encontraron en España, y considerados asimismo los períodos que transcurrieron juntos en Las Posadas -lugar de residencia de Silvestre- para sacar adelante el texto de La Florida ${ }^{15}$, es posible que el ejemplar de Gómara haya pasado a Garcilaso en préstamo, quizá más de una vez, antes de quedar definitivamente en su propiedad luego de la muerte del amigo $^{16}$. Se puede suponer, por consiguiente, que las aposti-

del Inca por algunas otras formas que se encuentran en los cronistas proviene de su idea de que se trataba de deformaciones españolas, cuando en verdad, en muchos casos (no en todos), parece haberse tratado de formas dialectales del propio quechua, ajenas a la variedad cuzqueña. Pero Atabalipa y Saire Topa son, en cualquier caso, versiones españolizadas (téngase en cuenta, sin embargo, que en la dedicatoria a Felipe II de los Diálogos de amor el Inca escribe Inca Gualpa Topac). Sobre todos estos asuntos cf. R. CERróNPalomino, "El Inca Garcilaso o la lealtad idiomática", Lexis, 15 (1991), 133178. Sobre Perú/Pirú cf. J. Durand, "Dos notas sobre el Inca Garcilaso", NRFH, 3 (1949), esp. pp. 284-290. Por lo que concierne a las apostillas, hay que decir que de cinco que indudablemente son de Garcilaso aparece Peru en cuatro ocasiones y Piru en una. Hay pocos casos dudosos, respecto de la autoría, en los que aparece Piru; la mayoría de las instancias de Piru son claramente de Silvestre.

15 Véase, a este propósito, J. Durand, "El proceso de redacción de las obras del Inca Garcilaso", Études Latino-Americaines, 1 (1962), 13-32, y "La redacción de La Florida del Inca", Revista Histórica, Lima, 1954, núm. 21. Cf. también A. Miró Quesada, op. cit., caps. 5 y 6.

${ }^{16}$ Silvestre murió a principios de 1592 (cf. J. DE la TORRE y del Cerro, $\mathrm{El}$ Inca Garcilaso. Nueva documentación, Madrid, 1935, p. xvi), y el Inca fue su albacea. Garcilaso, quien ya conocía a Silvestre del Perú, lo encontró en España (concretamente, en Madrid) por primera vez hacia 1562-1563. 
llas, tanto de uno como de otro, se hicieran en el curso de diversas lecturas a través de los años, lo cual puede haber incidido en las diferencias de escritura. Esta hipótesis me parece estar apoyada justamente por la anotaciones con las que Garcilaso identifica algunas del amigo perulero, en el sentido de que se explican mejor en un momento de lectura posterior a la muerte de Silvestre, cuando ya dispone más libremente del ejemplar y puede referirse a anotaciones anteriores y ajenas con el evidente propósito de singularizarlas para ser citadas con mención, si bien genérica, de su enunciador. Esto último ocurrió, efectivamente, en los dos casos, ya mencionados, que pasaron a la Historia general del Perú (15 y 55). De las dos apostillas restantes atribuidas al conquistador, una, la referente al Río de la Plata (19), no fue recogida literalmente, si bien Garcilaso, en más de una ocasión, alude a esa conquista y menciona algunos particulares de ella (véase el Comentario a 19). La otra (21), que consiste en una recusación global del libro de Gómara en lo que respecta al Perú, tampoco encontró lugar, quizá porque su radicalismo no era compatible con la actitud más bien ambigua de Garcilaso respecto del libro del soriano, que critica tanto en la privacidad de las apostillas cuanto en la apertura de los textos impresos, pero que también utiliza respetuosa y profusamente como fuente de constante apoyo.

En todo caso, este ejemplar de la obra de Gómara fue el empleado por Garcilaso en la redacción de diferentes partes de su obra, pues de él cita textualmente ${ }^{17}$ y de él se sirve, obviamente, por las apostillas, que, mayoritariamente, de una u otra manera, se reflejan o se integran en su propio texto. En algún caso (cf. 73) es evidente que la apostilla indica un lugar que debía ser tenido en cuenta para ser agregado a una redacción preexistente sobre el asunto.

Respecto de la autoría, conviene tratar brevemente una última cuestión. Hay apostillas que, por la letra, no parecen de

17 Por ejemplo, cuando narra la anécdota de Villacastín (cf. apostilla 15, Comentario), cita a Gómara donde éste dice, a propósito de las monas, que "enojadas gritauan"; ahora bien, ésta es lectura de nuestra edición, que omite otra precisión, a saber, que las monas "alegres cocauan", la cual se encuentra en ediciones anteriores. Sobre los problemas del texto de Gómara puede verse M. Mustapha, "Apuntes para una edición crítica de la Historia general de las Indias de F. López de Gómara”, en Edición y anotación de textos coloniales hispanoamericanos, eds. I. Arellano y J. A. Rodríguez Garrido, Universidad de Navarra-Iberoamericana-Vervuert, Madrid, 1999, pp. 261-270. 
Garcilaso, si bien han pasado sea total, sea parcialmente a su obra, o que, sin ser reconstruibles en el detalle, muestran una gran congruencia con el texto garcilasiano. Fuerte es la tentación de considerar estas circunstancias como criterios decisivos para una atribución al Inca de tales casos. Sin embargo, también aquí hay que proceder con mucha cautela. Silvestre fue informante de Garcilaso para los sucesos de La Florida pero también para muchos del Perú, y fácilmente se puede imaginar que las anotaciones de menor monta hechas por Silvestre fueran consideradas por Garcilaso como una especie de bien común que podía utilizarse sin mención específica de la fuente de origen. Esto coincide con lo que sabemos del tipo de relación entre ambos personajes, que en numerosas conversaciones exhumaban recuerdos de otras épocas de sus vidas, intercambiando información, probablemente enfrascándose en numerosos detalles y, eventualmente, revisando en común libros como el de Gómara, y anotándolos ${ }^{18}$. El estatuto de las apostillas de Silvestre, así, no era muy diferente al de las informaciones o precisiones que el Inca pudo haber obtenido oralmente en las mencionadas conversaciones a lo largo de los años, lo que podía justificar su uso sin mención de la fuente ${ }^{19}$. Por todas estas razones me inhibo de indicar la autoría en los casos dudosos (entre los cuales se encuentran también algunos ca-

18 Una vivaz recreación, con tintes novelescos, de la larga relación de Silvestre y Garcilaso, puede verse en Porras Barrenechea, p. 766. Para ponderar la fama de Silvestre como informante perulero no es irrelevante, aunque tardío, el testimonio de Íñigo de Córdoba Ponce de León, quien en una anotación manuscrita en un ejemplar de la primera edición de los Tratados del P. B. de las Casas que perteneció al Inca Garcilaso (y luego al padre del anotador, Diego de Córdoba), dice, luego de dar varios datos sobre Silvestre: "El dicho Garcilaso de la Vega quizá se fue a las Posadas y en compañía del dicho Gonçalo Silvestre escribieron los Comentarios Reales y el libro de La Florida y los demás libros". La anotación fue descubierta por el P. R. Vargas Ugarte y publicada en Mercurio Peruano, Lima, 1930, núms. $137 / 138$ (cito resolviendo las abreviaturas).

${ }^{19} \mathrm{La}$ actitud de Garcilaso de oscurecer la referencia a Silvestre por medio de una indicación de tipo genérico ("conquistador viejo", "conquistador del Perú”) no deja de ser algo enigmática. Si se puede entender que en Floridacallara el nombre del informante para quedar libre de convertirlo en uno de los héroes de la expedición, sin comprometer la credibilidad del relato, en el caso del ejemplar privado del libro de Gómara el silenciamiento no tiene explicación clara. ¿Proteger a Silvestre (¿de qué?, ¿de quién?) por sus opiniones y juicios violentos y lapidarios? Sobre estos problemas puede verse J. Durand, "Los silencios del Inca Garcilaso", Mundo Nuevo, Paris, 1966, núm. 5, 66-72. 
sos de apostillas muy breves, las cuales no ofrecen base suficiente para la identificación de su autor) y me limito a marcar con una $<\mathrm{G}>$ o con una $<\mathrm{S}>$ los que creo unívocos, sobre la base de criterios gráficos o de otro orden; a tales iniciales añado un punto de interrogación cuando me parece haber un grado menor de seguridad. También entre paréntesis añado la atribución de Porras Barrenechea $(P B)$, cuando no es coincidente con la mía (pero la ausencia de la sigla $P B$ en otros casos quiere decir que este estudioso no se pronuncia a propósito de ellos). Algunas veces aludo a los problemas de autoría en el Comentario.

En la reproducción se respeta la grafía del original, pero las abreviaturas se resuelven en cursiva. Letras o palabras faltantes por deterioro del ejemplar se indican entre corchetes []; cuando la reconstrucción o la lectura son menos seguras se añade un signo de interrogación. Los puntos suspensivos dentro de los corchetes indican que se ha perdido una porción de texto que no se puede reconstruir; un signo de interrogación luego de los puntos indica que la laguna no es del todo segura. Las porciones en cursiva dentro de los corchetes son del editor. Otras indicaciones del editor, por ejemplo, las referentes a lagunas mayores en el texto de las apostillas o las que complementan algún texto citado, van siempre en cursiva y se ponen entre paréntesis angulares $<>$. Algún caso de ditografía se indica por medio de llaves \{\}. Se separan por medio de doble barra / / las líneas de las apostillas, a fin de que se pueda reconocer el lugar en el que ha incidido el deterioro material y se pueda evaluar, por lo tanto, la propuesta de reconstrucción de las porciones perdidas. Las excepciones a esta norma se indican en los lugares respectivos del comentario. La barra simple / es del texto original.

\section{EDICIÓN Y COMENTARIO 20}

1) Fol. VIr, cap. 13, margen inferior.

fr. antonio fernandez natural de palos el qual contratava en Las Canar//ias i que por primero se le deve la groria, y no a Colon $<\mathrm{S}>$

${ }^{20}$ Utilizaré las siguentes abreviaturas y siglas: Acosta = J. DE Acosta, Historia natural y moral de las Indias, Juan de León, Sevilla, 1590; Cieza = P. DE Cieza de León, Primera parte de la Crónica general del Perú, Martín Montesdo- 
Comentario. La apostilla se refiere al inicio del capítulo que trata "Del descubrimiento primero de las Indias", anterior al de Colón. En él, Gómara discurre asimismo sobre la posible identidad del protagonista y lamenta que no se conozca su nombre. La apostilla señala el nombre no mencionado por Gómara. Como bien observa Porras Barrenechea (p. 758), es raro que Garcilaso, quien llama en $C R$, lib. I, cap. 3, Alonso Sánchez de Huelva al piloto desconocido, no recogiese esta indicación. A. Miró Quesada, al tratar del asunto del 'predescubrimiento', indica que el primero en dar el nombre del piloto fue Garcilaso, pero no menciona este antecedente de la apostilla ${ }^{21}$, en la cual también están aludidas las Canarias. Entre las varias versiones que circularían en el Perú y España al respecto, Garcilaso prefirió desechar la del marino de Palos en beneficio del de Huelva. $P B$ lee "y antes por primero se le deve". Obsérvese, por lo demás, el vulgarismo fonético por asimilación anticipatoria de $l$ a $r$.

2) Fol. VIIr, cap. 15, margen derecho inferior.

$$
\text { monje jer }[\mathrm{o}] / / \text { nimo } / / 1486<\mathrm{S}>
$$

Comentario. La apostilla está referida a fray Fernando de Talavera, el confesor de la reina Isabel, mencionado por Gómara

ca, Sevilla, 1553; CR = InCA GaRCiLASO DE LA VeGA, Commentarios Reales, que tratan del origen de los Yncas..., eds. I. Arellano y J. A. Rodríguez Garrido, Pedro Crasbeek, Lisboa, 1609 (1608 en el colofón). En este caso y en el de Historia general del Perú cito por las ediciones de A. Rosenblat, Buenos Aires (Emecé, $1945^{2}$ y 1944 , respectivamente), pero, para ciertos pasajes que indico, utilizo la edición princeps de ambas obras; Fac.= reproducción facsimilar de F. LóPez de Gómara, Historia general de las Indias, Pedro Bernuz, Zaragoza, 1554 (cf. supra, n. 7); Florida = InCA Garcilaso de la VeGA, La Florida del Ynca, Pedro Crasbeek, Lisboa, 1605. Cito por la ed. de Obras del Inca Garcilaso de la Vega, a cargo de C. Sáenz de Santa María, Madrid, BAE, 1963, t. 1; HPerú = Inca Garcilaso de la Vega, Historia general del Perú, Viuda de Andrés Barrera, Córdoba, 1617; Palentino = D. Fernández de Palencia, Primera y segunda parte de la Historia del Perú, Hernando Díaz, Sevilla, 1571; $P B=\mathrm{R}$. Porras BarreNECHEA, "Una joya bibliográfica peruana" (cf. supra, notas 1 y 3 ); Zárate = A. de ZÁrate, Historia del descubrimiento y conquista del Perú, Martín Nucio, Amberes, 1555 .

21 "El Inca Garcilaso y las islas Canarias", en Tiempo de leer, tiempo de escribir, Lima, 1977, pp. 51-79, aquí p. 54. 
en el contexto de la llegada de Colón a la corte de Castilla en 1486. En HPerú, lib. I, cap. 5 ("Lo que costó a los Reyes de Castilla el Nuevo Mundo") hay una extensa cita tomada de este capítulo de Gómara, cita que comprende la mención de Talavera y de la fecha antedicha. Garcilaso no agrega la precisión sobre la orden del religioso.

3)Fol. VIIIr, cap. 16, margen derecho inferior.

$\operatorname{con}[\mathrm{ejos}]$

Comentario. Repite la palabra que en el texto de Gómara aparece como equivalente de hutias: "conejos que llaman hutias". Fac. lee, contra toda evidencia, "canes" y agrega una "e", que más parece "i", a las tres letras que quedan en el original. $\mathrm{Hu}$ tías es arahuaquismo temprano, ya conocido por Colón (se encuentra, en efecto, en una de las apostillas, probablemente de Colón, al libro de Marco Polo, como equivalente de los ratti Pharaonis ${ }^{22}$ ). Los equivalentes más frecuentes en los textos antiguos son ratones y conejos (cf. 7).

4)Fol. VIIIv, cap. 17, margen izquierdo central.

[por] [Ca]stilla //[y por] [L]eon //[nue]vo mun//[do] [hall]o Colo $n<\mathrm{G}$ ? $>$

Comentario. Repite el texto que forma parte del escudo de armas de Colón, señalado por Gómara. Las partes reconstruidas se han perdido por el refilado. En $C R$, lib. I, cap. 3, Garcilaso cita el dístico, que Colón puso "por blasón en sus armas", en otra variante, a saber: "A Castilla y a León, Nuevo Mundo dió Colón”. Lo que se conserva de la anotación manuscrita también es compatible con esta versión.

22 Cf. Juan Gil, El libro de Marco Polo/Las apostillas a la Historia Natural de Plinio el Viejo, Alianza, Madrid, 1992. 
5) Fol. IXr, cap. 20, margen derecho inferior y margen inferior.

miente $\mathrm{E}[1][\mathrm{au}] / /$ tor en de[zir] // que el oficio [de] [pla]//tero es $\mathrm{m}[$ ecani] //co siendo [...?] // inuintiv[o] [...?] // el enten [dimien] //to pues [...?] [los?] [re?] //yes usan d [el] $\langle P B$ : S $\rangle$ Esto puso un platero $<\mathrm{G}>$

Comentario. Las dos apostillas pertenecen al mismo contexto, ya que la segunda (que se encuentra a la izquierda de la primera, en el margen inferior) identifica al autor de la primera. Si bien las letras de ambas son parecidas, hay algunos rasgos que las distinguen, por ejemplo, el trazo de la "e". La primera mano, por lo demás, escribe "platero" sin abreviatura. $P B$ cree que la primera es de Silvestre y la segunda, como comentario irónico, de Garcilaso. Pero en las apostillas que indudablemente son de Silvestre la letra es diferente a la de la presente. En cambio, la segunda apostilla está escrita, patentemente, por Garcilaso. Si esto es así, entonces hay que considerar la posibilidad de un tercer anotador del texto de Gómara, a saber, el platero aludido por Garcilaso. En cuanto al contenido de la anotación, se trata de una reivindicación del carácter "no mecánico" (y, por lo tanto, liberal o "inventivo") del oficio de platero, probablemente basada en la dignidad del destinatario o usuario de los bienes producidos. Esta interpretación, que he desarrollado y fundamentado en otro lugar ${ }^{23}$, me ha llevado a la reconstrucción propuesta, en la que se alude a los reyes. Pero la conjetura podría ser distinta e implicar una mención a "leyes", lo cual, naturalmente, condiciona también una continuación diversa.

6) Fol. XIr, cap. 24, margen derecho superior.

Eclipse d[e] / / la luna

Comentario. Entre las dos primeras palabras y las dos últimas aparece una marca de relieve consistente en dos puntos, de entre los cuales parte una línea ligeramente ondulada. Corres-

23 "Una anotación manuscrita sobre los plateros en la Historia general de las Indias de F. López de Gómara", en Homenaje a Don Aurelio Miró Quesada Sosa, ed. H. López Martínez, Academia Peruana de la Lengua-Academia de la Historia-Consorcio de Universidades, Lima, 1998, pp. 381-387. 
ponde al lugar en el que Gómara refiere la anécdota atribuida a Colón, según la cual éste, al regreso del cuarto viaje, logró el apoyo de los indios de Jamaica, reacios a socorrerlo, amenazándolos con la transformación de la luna como consecuencia de un eclipse de cuya inminencia el Almirante estaba enterado. La anécdota proviene de la biografía de Hernando Colón, cap. 103. En $C R$, lib. II, cap. 23, Garcilaso se refiere a la interpretación que los indígenas peruanos daban a los eclipses de sol y de luna; en su descripción parece resonar el eco de esta lectura. Cf.: "Al eclipse de la luna, viéndola ir negreciendo, dezían que enfermava la luna, y que si acabava de escurecerse havía de morir y caerse del cielo y cogerlos a todos debaxo y matarlos, y que se havía de acabar el mundo".

7)Fol. XIVr, cap. 34, margen derecho superior.

hutias // conejos

Comentario. Se refiere a la mención de "una dozena de hutias" en el texto de Gómara. El anotador hace explícita la sinonimia que estaba presente en el pasaje de Gómara al que se refiere la apostilla 3. Fac. dibuja una "y" que no aparece en el texto de la anotación.

8) Fol. XIVr, cap. 35, margen derecho central.

Santo Dom[in] / go $<\mathrm{G}>$

Comentario. Se refiere al pasaje en el que Gómara da las razones del nombre puesto a la principal ciudad de la Española. Dicho pasaje fue citado literalmente (aunque con ciertos retoques ortográficos) en $C R$, lib. I, cap. 7:

La ciudad de Sancto Domingo, por quien toda la isla se llamó del mismo nombre, se fundó y nombró, como lo dize Gómara, capítulo treinta y cinco, por estas palabras que son sacadas a la letra: "El pueblo más ennoblescido es Sancto Domingo, que fundó Bartolomé Colón a la ribera del río Ozama. Púsole aquel nombre porque llegó allí un domingo, fiesta de Sancto Domingo, y porque su padre se llamava Domingo. Assí que concurrieron tres causas para llamarlo assí”, etc. 
Para el interés de Garcilaso en el origen de los topónimos cf. 11.

9) Fol. XVv, cap. 42, margen izquierdo inferior.

[A]yllon / / [1]520<G>

Comentario. El nombre aparece al inicio del capítulo en el que se trata del descubrimiento del río Jordán a cargo de Lucas Vásquez Ayllón. La fecha se encuentra debajo algo separada y se refiere al año del mismo. Ambos datos se encuentran en Gómara. Garcilaso trata el asunto en Florida, lib. I, cap. 3.

10) Fol. XVIIr, cap. 44, margen derecho central.

Bezerri $[1 l o]<\mathrm{G}>$

Comentario. El nombre aparece al cabo de una línea ondulada vertical que resalta el pasaje en el que Gómara se refiere a la valentía con la que se señaló en la conquista de Puerto Rico el soldado Diego de Salazar, el cual era ayudado por un fierísimo perro llamado Becerrillo,

...bermejo, bocinegro y mediano, que ganaua sueldo y parte como ballestero y medio: el qual peleaua contra los Indios animosa e discretamente y conocia los amigos y no les hazia mal aunque le tocassen. Conocia qual era Caribe y qual no. Traya el huydo aunque estuviesse en medio del real de los enemigos, o le despedaçaua. En diziendole ydo es, o buscaldo, no paraua hasta tornar por fuerça al Indio que se yua. Acometian con el nuestros españoles tan de buena gana como si tuuieran tres de cauallo. Murio Bezerrillo de vn flechazo que le dieron con yerua, nadando tras un Indio Caribe. (Cf. 14).

11) Fol. XXIr, cap. 52, margen derecho inferior.

nombres / / puestos a / / caso $<\mathrm{G}>$ Yucatan $<\mathrm{G}>$

Comentario. Las dos apostillas señalan el pasaje en el que Gómara trata de nombres que los descubridores pusieron a determi- 
nados lugares sobre la base de un malentendido con los indígenas. Particularmente, Gómara se refiere a "Cotoche" y a "Yucatán". Todo el pasaje fue citado por Garcilaso en $C R$, lib. I, cap. 5, en el contexto de su explicación del nombre "Perú"24.

12) Fol. XXIr, cap. 52, margen inferior.

Conquista de Mexico. fol. 519

Comentario. Se refiere al pasaje en el que Gómara dice: "Quando hablare de la isla Acuçamil, tratare mas largo esto de las cruces”. Acuçamil aparece subrayado por el anotador. La apostilla alude al lugar al que remite Gómara en la Historia de la conquista de México. Líneas antes Gómara se refiere a las cruces de latón y palo que se hallaron en tumbas de Yucatán. Sobre el margen izquierdo hay dos líneas pequeñas que ponen de relieve esta mención. Cf. a este propósito $C R$, lib. II, cap. 3, en el que se hace referencia a la "cruz de mármol fino, de color blanco y encarnado" que tuvieron los incas en el Cuzco. Sobre las cruces cuzqueñas véase también HPerú, lib. I, cap. 32.

13) Fol. XXVv, cap. 60, margen izquierdo central.

[r]eprehension // [de] vn Yn//[di]o a los // [españo]les $<$ G? $>$

Comentario. La apostilla, bajo la cual hay una rúbrica que parece de Garcilaso, resume la intervención del cacique Panquiaco frente a la riña de los españoles de Vasco Núñez de Balboa por la repartición del oro y las piedras preciosas que les había entregado.

14) Fol. XXIXr, cap. 65, margen derecho central.

Bezerr[illo] // y Leoncill[o] // lebreles $<\mathrm{G}>$

Comentario. La apostilla señala el lugar en el que Gómara se refiere el perro Leoncillo, hijo de Bezerrillo, ya nombrado (cf. 10). El texto de Gómara es el siguiente:

24 A este propósito cf. G. L. Guitarte, "Bernardo de Aldrete, el Inca Garcilaso y el nombre del Perú”, AnMal, 21 (1998), 483-502. 
Repartio Valboa el oro entre sus compañeros despues de quintado para el rey: y como era mucho alcanço a todos, y aun mas de quinientos castellanos a Leoncillo, perro hijo de Bezerrillo el de Boriquen, que ganaba mas que arcabuzero para su amo Valboa: pero bien lo merecia segun peleaua con los Indios.

Garcilaso en Florida, lib. II, 1, cap. 18, dedica un párrafo, evidentemente inspirado en Gómara, a ambos lebreles:

Cosas de grande admiración han hecho los lebreles en las conquistas del nuevo mundo como fue Becerrillo en la isla de San Juan de Puerto Rico, que de las ganancias que los españoles hacían daban al perro, o por él a su dueño, que era un arcabucero, parte y media de arcabucero, y a un hijo de este lebrel, llamado Leoncillo, le cupo de una partija quinientos pesos de oro de las ganancias que el famoso Vasco Núñez de Balboa hizo después de haber descubierto la mar del Sur.

15) Fol. XXIXv, cap. 66, margen inferior y margen izquierdo.

$[u]$ na hirio con una piedra a un vallestero que se dezia villacastin que despues fue // [con]quistador del piru y se[ñor] de un buen repartimiento que se dize ayauire es[tuv] o preso [en] // el cuzco por que se hallo de la parte de piçarro en xaquixaguana don[de] [le dio] una cuchi//[llada] [en la cara] despues de r[end]ido vno qu[e] estau[a] [mal con el fue] [hom]bre de bien // [y que hizo mucho bien a muchos aunque murio pobre y despojado de indi] os [y de hazienda] / / <sigue en el margen izquierdo de través $>\mathrm{El}$ villacastin mato la mona que le hirio por qu[e] a un [tiempo] acertaron a soltar El su balesta $<s i c>$ y la [mona la piedra] $<\mathrm{S}>$

Comentario. Esta apostilla, que comienza en el margen inferior y termina - como se indica en la transcripción-con una línea escrita de través en el margen izquierdo, está muy deteriorada por roturas del papel. Aparece atribuida por Garcilaso, en otra apostilla en el margen inferior de la página siguiente (cf. 16), a "vn conquistador del Peru". La reconstrucción propuesta se basa en la cita casi literal de Garcilaso (quien corrige la escritura de los topónimos y agrega el detalle de los dientes) en $C R$, lib. IX, cap. 38, donde cuenta la anécdota y hace referencia a encontrarse en el ejemplar de Gómara. En su versión 
incluye también, en parte, la propia apostilla respecto del mismo tema (cf. 16). He aquí el pasaje completo de Garcilaso en el lugar mencionado (cito aquí por la princeps, pero resuelvo las abreviaturas):

Vn cuento historial digno de memoria se me ofresce del, y es que, Francisco Lopez de Gomara dize en su historia, capitulo sesenta y seis estas palabras, que son sacadas a la letra. Poblo Pedrarias el Nombre de Dios y a Panama. Abrio el camino que va de vn lugar a otro con gran fatiga y maña, por ser de montes muy espessos y peñas; auia infinitos Leones, Tigres, Ossos, y Onças a lo que cuentan, y tanta multitud de monas de diversa hechura y tamaño, que enojadas, gritauan de tal manera que ensordecian los trabajadores, subian piedras a los arboles y tirauan al que llegaua. Hasta aqui es de Gomara: vn conquistador del Peru tenia marginado de su mano vn libro que yo vi de los de este Autor, y en este passo dezia estas palabras, vna hirio con una piedra a vn vallestero que se dezia Villacastin, y le derribo dos dientes, despues fue conquistador del Peru, y señor de vn buen repartimiento que se dize Ayauiri, murio preso en el Cozco, porque se hallo de la parte de Piçarro en Xaquixaguana, donde le dio vna cuchillada en la cara despues de rendido uno que estaua mal con el: fue hombre de bien, y que hizo mucho bien a muchos, aunque murio pobre, y despojado de Yndios y hazienda. El Villacastin mato la mona que le hirio, porque a vn tiempo acertaron a soltar, el su ballesta, y la mona la piedra: hasta aqui es del conquistador, e yo añadire que le vi los dientes quebrados, y eran los delanteros altos, y era publica voz y fama en el Peru auerselos quebrado la mona; puse esto aqui con testigos por ser cosa notable, y siempre que los hallare holgare presentarlos en casos tales.

16) Fol. XXXr, margen inferior.

Esta nota de Villa castin con la mona la puso vn conquistador del Peru/. y yo alcance al Villacastin // tenia menos dos dientes los delanteros altos que la mona le derribo de la pedrada, dos hijos suyos fuero $n / /$ mis condiscipulos de leer y escriuir. Garcilasso $\langle$ rúbrica $>$. $<\mathrm{G}>$

Comentario. Cf. el comentario a la apostilla anterior. En el citado pasaje de $C R$ Garcilaso incorpora el contenido de esta apostilla, si bien elimina la referencia a su relación con los hijos de Villacastín. 
17) Fol. XXXVr, cap. 77, a continuación del título.

Este fue despues obispo de Chiapa

Comentario. El capítulo, que trata "De la muerte de muchos Españoles cruzados que lleuo Bar[t] holome delas Casas clerigo", fue íntegramente citado por Garcilaso en el contexto de su crítica a Las Casas (HPerú, lib. IV, cap. 3), como responsable de las "Leyes Nuevas". Esta crítica se transmite a través de este capítulo de Gómara, complementado con lo que decían los conquistadores del Perú, quienes, según Garcilaso, declaraban mejor lo que Gómara "va cifrando". Al fin del mencionado capítulo del libro IV, el Inca consigna el dato que contiene la presente apostilla, agregando que Las Casas no osó pasar a Chiapas "por lo que en las Indias havía causado". Asimismo, da cuenta de su encuentro con el dominico en España: "Yo lo alcancé en Madrid año de quinientos y sesenta y dos, y porque supo que yo era de las Indias me dió sus manos para que se las besasse, pero cuando entendió que era del Perú y no de México, tuvo poco que hablarme".

18) Fol. XXXVIIIv, cap. 85, margen izquierdo inferior.

[ar]boles // [g]randes

Comentario. Se refiere al pasaje de Gómara (parcialmente subrayado) que se encuentra al final del capítulo sobre los descubrimientos notables de Vicente Yáñez Pinzón por "rio Marañon, rio Orellana". En él se dice: "Traxeron los descubridores cortezas de ciertos arboles que parecia canela, y un cuero de aquel animal grande que mete a los hijos en el pecho, y contauan por gran cosa hauer visto arbol que no le abraçaran dieziseys hombres". Todo el pasaje está citado por Garcilaso en HPerú, lib. III, cap. 14, en el contexto del final del viaje de Gonzalo Pizarro a la Canela.

19) Fol. XXXIXv, cap. 89, margen inferior y folio XLr, cap. 89, margen inferior y derecho (de través).

El año de mill y quinjentos quarenta y tres salieron del piru ccxxx Españoles de a cauallo / / muchos dellos con tres y quatro y cinco cauallos llevando por capitanes a diego de // rojas y felipe gutie- 
rre $[\mathrm{z}]$ descubrieron muchas y grandes provincias y no se sabe // [...] [ca]minasen y descubriesen tanto llegaron hasta el rio de la plata <laguna de casi una línea $>$ fue sebastian < sigue en XLr> / / gaboto / En todo lo que anduvieron no hallaron mas ruines yndios de guerra $\mathrm{q}[\mathrm{ue}] / /$ los de Este rrio / tardaron tres a ños y medio En este descubrimjento / no poblaron por <que testado $>$ no halla[r] // tierra rica y lo principal por muerte de djego de rojas de que resulto pasiones y rebuelta[s] // Entre ellos y asi se tornaron al piru no faltando de todos ellos treinta aunque siem[pre] // $<$ laguna de una línea por refilado; continúa en el margen derecho de través $>$ [avien?] do de la ciudad de los reyes que es En el piru hasta el rio de la plata donde llegaron Estos Españoles setecientas leguas // En todos los tres años y medio nunca pararon ni se vieron juntos todos mes Entero despues que Entraron En tierra de guerra que [lo] // mantuvieron siempre / porque vno[s] yuan a descubrir y otros quedauan En el real y venido $<$ sic $>$ aquellos yuan estos // y [...] de parte ninguna / y quando se bolvieron al piru Enterraron todo El hierro y herraje que les sobro < sigue un signo, quizá " $j$ ", lo que podría indicar que el texto continuaba $><\mathrm{S}>$

Comentario. Esta anotación comienza con sólo las primeras cuatro palabras en el fol. XLr, al final del cap. 89, en el que se habla "Del rio de la Plata y de lo que en su descubrimiento acontecio a Solis". Un asterisco debajo de dichas palabras indica la continuación en el margen inferior, fol. XXXIXv, del cual luego pasa al margen inferior y luego al margen derecho (al través) del fol. XLr. Se trata de una apostillla del "conquistador viejo", como señala el propio Garcilaso en otra apostilla escrita en el margen izquierdo del fol. XLr (cf. 20). Efectivamente, la letra corresponde a aquella de la anotación 15. Está muy deteriorada por roturas y refilado del papel: faltan parcial o totalmente las líneas finales de lo anotado en los márgenes inferiores de XXXIX y XL. En el capítulo sobre el río de la Plata, Gómara da cuenta de las expediciones de Solís, Gaboto, Mendoza y Cabeza de Vaca, además de las noticias de tipo etnológico sobre la región. El "conquistador viejo" completa la información con el relato de una expedición terrestre partida desde el Perú. En HPerú, lib. III, cap. 19, se menciona esta expedición (en la que "passaron grandíssimos trabajos") y a los que la acaudillaron, a saber, Diego de Rojas, Nicolás de Heredia y Felipe Gutiérrez. Garcilaso vuelve a referirse a la misma en el lib. IV, cap. 37, donde cuenta, entre otras cosas, el regreso de los expedicionarios al Perú. 
20) Fol. XLr, margen inferior central.

Todo esto / / añadido / / de mano / / es vn $<$ sic $>$ con / / quistador $/ /$ viejo $<\mathrm{G}>$

Comentario. Cf. 19.

21) Fol. XLIXr, cap. 108, margen derecho superior

grande agrau[io] // [se] le haze a ti[e]//rra y rey // [y a] [s] us descubr[i] //[dores] y conquis[ta]//dores En le c[reer] // [a] [es] ta historia // [y] no a quie[nes] // [...] de t[iempo] antiguo $[\ldots] / /$ [la] [na]cion Espa//ñola que $[\ldots] / /[\ldots]$ supiero[n] // [...] er hazaña[s] // [ant] es que r $[$ ela//ta]rlas y Es[to] // [es lo?] mayor de [...] // [su] [o]bra y [...]// [el] [descubri] miento // [y] [tod] a la conquista // [...] del nueuo // mundo qu[e] // [to]da Es obra // de braços es//pañoles $<\mathrm{S}>$

Comentario. Esta apostilla pertenece nuevamente al "conquistador del Peru”, como lo señala Garcilaso en la misma página (cf. 22). Está muy mal conservada y no puede reconstruirse en todos sus extremos. Al lado derecho falta alguna letra por el refilado; en el lado izquierdo, que se sobrepone a una ilustración y está raspado, no se pueden leer varias letras, de las cuales quedan algunos rastros no descifrables. Sin embargo, la reconstrucción permite entender el sentido de la apostilla, que contiene una recusación global de la versión de Gómara sobre la conquista del Perú. Significativamente, la apostilla aparece al inicio de esta materia, en el capítulo titulado "Del rico y famoso descubrimiento del Peru". En Fac. muchas letras han sido repasadas o agregadas.

22) Fol. XLIXr, cap. 108, margen derecho superior.

Esta nota [es] // de un conqu[ista] //dor del $\operatorname{Per}[\mathrm{u}]<\mathrm{G}>$

Comentario. Apostilla situada encima de 21. 
23) Fol. Lr, cap. 109, margen derecho central.

Donde le [echa]//ron dos leo[nes] // los quales se [fue]//ron a el y [se] // echaron a [sus] // pies $\langle P B: G>$

Comentario. La apostilla corresponde al capítulo que trata el segundo viaje descubridor de Pizarro, y, particularmente, la misión encargada a Pedro de Candía de explorar Tumbes, exploración de la cual vuelve "espantado delas riquezas dela casa del rey Atabaliba”. La anotación agrega una anécdota ocurrida a Candía durante su misión. Garcilaso alude a esta anécdota, sin especificarla, en $C R$, lib. II, cap. 3 y lib. IX, cap. 7; luego la narra detalladamente (ampliando a Cieza, cap. 53) en HPerú, lib. I, caps. 11 y 12, y la retoma brevemente en el 32 el mismo libro.

24) Fol. Lr, cap. 109, margen inferior.

duro el $\mathrm{de}[\mathrm{scu}] / /$ brimiento mas $[\mathrm{de}] / /$ tres años

Comentario. Apostilla que se encuentra inmediatamente debajo de la anterior y que repite, con leve variación, el texto de Gómara, a saber: "Anduuo Francisco Piçarro mas tres años en este descubrimiento que llamaron del Peru, passando grandes trabajos, hambres, peligros, temores y dichos agudos". En $C R$, lib. IX, cap. 14, el Inca se refiere al "primer descubrimiento" del Perú a propósito de las navegaciones de Núñez de Balboa y a las noticias que tuvo de ellas Huayna Cápac. A continuación, alude a la duración del posterior descubrimiento por parte de Pizarro y sus camaradas. Asimismo, en HPerú, lib. I, cap. 13, dice literalmente: "Gastaron estos treze españoles <los trece de la isla del Gallo> más de tres años en este descubrimiento del Perú, como lo testifican aquellos autores < Gómara y Zárate>". Luego cita un fragmento de Zárate y, a continuación, el pasaje de Gómara (transcrito arriba) al que corresponde la apostilla. Repite la duración del descubrimiento en HPerú, lib. II, cap. 17.

25) Fol. Lv, cap. 110, margen izquierdo superior.

O Piru. 
Comentario. La apostilla señala el vocalismo alternativo del nombre, pues corresponde al siguiente texto de Gómara: "Tuuo [Pizarro] contrario viento para llegar a Tumbes, y desembarco en la tierra propiamente del Peru" (cf. nota 14).

26) Fol. Lv, cap. 110, margen izquierdo central.

del Peru // [an] tes de la y[da] // de Piçarro <G $>$

Comentario. Señala el lugar del texto en el que Gómara se refiere a la posibilidad de que fuera Balboa el primero en tener relación de la tierra del Perú, rica en oro y esmeraldas. El pasaje de Gómara está citado textualmente en $C R$, lib. I, cap. 6 .

27) Fol. LIv, cap. 112, margen izquierdo central.

[no] [sa]be lo quese di// [ze] [e]n la exposi//[cion] del vocablo// [co]nfunde dos//[voc] ablos de di//[stint] as significaciones// [com] o se decla//[rar]a en nuestra//[Histori] a del Peru/ $<\mathrm{G}>$

Comentario. Es la primera de las anotaciones de interés lingüístico (quitadas las equivalencias léxicas de 3 y 7), con la cual Garcilaso rectifica una ligereza interpretativa, por etimología popular, de Gómara, quien dice lo siguiente:

Embio [Pizarro] delante tres Españoles con ciertos naturales en una balsa a pedir paz y entrada. Los de Tumbez recibieron aquellos tres Españoles deuotamente: ca luego los entregaron a unos sacerdotes, que los sacrificassen a cierto idolo del sol llamado Guaca, llorando: y no por compassion, sino por costumbre que tienen de llorar delante la Guaca, y aun Guaca es lloro, y guay boz de rezien nacidos.

En las palabras "Guaca, llorando" hay un subrayado y un signo de llamada al margen, inmediatamente antes de la apostilla (cf. también 38). Por lo demás, ésta contiene la alusión a un proyecto, el de los Comentarios, nombrado todavía de modo genérico como Historia del Perú, nombre que, finalmente, se aplicaría sólo (no se sabe si por voluntad de Garcilaso o de los editores) a la segunda parte de la obra principal del Inca, con el adjetivo "general": Historia general del Perú. El refilado ha 
hecho que desaparezcan varias letras, como se indica en la transcripción; llamo la atención -por su importancia respecto del carácter de proyecto que tenían los Comentarios en esta épo$\mathrm{ca}-$ sobre el hecho de que es necesario reconstruir un futuro, a saber, "declarara", teniendo en cuenta dos letras perdidas, en vez de "declara" (como en Fac.).

28) Fol. LIIr, cap. 113, margen derecho inferior.

usuta / / chipana $<\mathrm{G}>$

Comentario. La apostilla consiste en los nombres quechuas de los objetos mencionados en español en el texto de Gómara, a saber, "çapatos pintados" y "puñetes de oro". Se trata del pasaje en el cual Pizarro afirma al mensajero de Atahualpa su voluntad de llegar a Cajamarca: "Entonces el Indio le dio unos çapatos pintados y unos puñetes de oro que se pusiesse, para que Atabaliba su señor lo conociesse...". En HPerú, lib. I, cap. 17, luego de referir ampliamente el diálogo entre el embajador del Inca y Pizarro, y de mencionar por extenso los regalos enviados por Atahualpa al gobernador (entre ellos, dos "braçaletes de oro que llaman chipana"), Garcilaso comenta:

Desta embaxada, dádivas y presentes, con ser tan grandes y ricos, ni del embaxador, con ser hermano del Rey, ni de la respuesta del governador, no haze relación Gómara ni Agustín de Çárate; solamente dizen del calçado y braçaletes que en particular truxeron al governador, y ambos les llaman puñetes, como si fueran puñetes de camisa, no advirtiendo que los indios del Perú, en su hábito natural, nunca truxeron camisa.

$P B$ (p. 762) transcribe equivocadamente "ujuta", con forma semiespañolizada ${ }^{25}$. Sobre usuta y chipana $\mathrm{cf}$. $C R$, lib. VI, caps. 25 y 22 , respectivamente.

29) Fol. LIIv, cap. 108, margen izquierdo inferior.

[resp]uesta de // [ata]balipa $<$ S $>$

${ }^{25}$ Véase también, a este propósito, infra, nota 35. 
Comentario. La apostilla alude al pasaje en el que Gómara reporta la respuesta de Atahualpa a la intimación de fray Vicente Valverde, poco antes del ataque de las fuerzas de Pizarro. La versión que de este episodio da el Inca se encuentra en HPerú, lib. I, cap. 24. Atabalipa es la forma corriente entre los cronistas españoles y ajena a Garcilaso.

30) Fol. LIIIr, cap. 113, margen izquierdo superior.

Buen conse / /jo de frajle $<\mathrm{S}>$

Comentario. El texto de Gómara al que se refiere la apostilla es el siguiente: "Murieron tantos <indios, en el ataque de Cajamar$c a>$, porque no pelearon: y porque andauan los nuestros a estocadas, que assi se lo aconsejaua fray Vicente por no quebrar las espadas, hiriendo de tajo y revés". La parte subrayada aquí aparece subrayada en el ejemplar y está citada por el Inca en $H P e^{-}$ rú, lib. I, cap. 26, quien la desmiente:

Lo que dizen del Padre Fray Vicente de Valverde, que tocó arma pidiendo vengança contra los indios, y que aconsejava a los españoles que no hiriessen de tajo ni revés sino de estocada, por que no quebrasen las espadas, y que por esto fué la mortandad de los indios tan grande, ello mesmo dize que fué relación falsa que hizieron a los historiadores que escriven en España lo que passó tres mil leguas della. Que no es de imaginar, cuanto más de creer, que un fraile católico y teólogo dixesse tales palabras, que de un Nerón se pueden creer, mas no de un religioso que por su mucha virtud y buena doctrina meresció ser obispo y murió a manos de indios por predicar la fe católica.

31) Fol. LIIIr, cap. 114. Espacio entre dos capitulos y margen derecho central.

que se dezia miguel astete que fue // despues vezino de guamanga Este cobro la borla que // traya por ynsinja real // despues la restituy[o] // a saire topa ynga [que] // salio de paz [en] // tiempo del visor[rey] // Diego hurtad[o] [de] // mendoça $\mathrm{m}$ [arques] // de cañete y [lo] // agradecio [el] [yn]//ga muy $\mathrm{mu}[\mathrm{cho}] / /$ y se lo pago [muy] // bien $<\mathrm{S}>$ 
Comentario. La apostilla se refiere a la última frase del relato que hace Gómara de los sucesos de Cajamarca: "No quedo muerto, ni herido ningun Español, sino Francisco Piçarro en la mano, que al tiempo de asir a Atabalipa, tiro un soldado una cuchillada para darle y derribarle, por donde algunos dixeron que otro lo prendio". Este pasaje aparece citado en HPerú, lib. I, cap. 27; a continuación se agrega lo que dice la apostilla:

Añadiendo a su historia lo que le falta (como lo tenemos propuesto) dezimos que este soldado se llamava Miguel Astete; fué después vezino de la ciudad de Huamanca, donde tuvo indios de repartimiento. Al caer de Atahuallpa, le quitó este soldado la borla colorada que en la frente traía en lugar de corona, y se quedó con ella. Por esto dixeron que lo havía preso él y no Don Francisco Piçarro. Mas como quiera que haya sido, andando ambos tan juntos se deve dar la honra al capitán. Miguel Astete guardó la borla hasta el año de mil y quinientos y cincuenta y siete, que salió el Inca Sairitúpac de las montañas donde estava retirado, y se la restituyó, como en su lugar diremos.

Sobre esto último cf. HPerú, lib. VIII, cap. 11

32) Fol. LIIIv, cap. 114, margen izquierdo superior.

[h] erraduras de // [o]ro y plata

Comentario. La apostilla pone de relieve el siguiente pasaje del texto de Gómara referente a los tesoros descubiertos por Hernando Pizarro: “...y traxo < Hernando Pizarro $>$ harta plata y oro. Entonces herraron los caballos con plata, y algunos con oro, porque se gastaua menos, y esto a falta de hierro". La última frase está citada por el Inca en HPerú, lib. I, cap. 29.

33) Fol. LIIIv, cap. 115, margen izquierdo central.

[p]rofecia de // [H] uaynaca//pac $<\mathrm{G}>$

Comentario. La apostilla pone de relieve el pasaje en el cual el texto de Gómara da cuenta, en discurso indirecto atribuido a Huáscar, del mandado que a éste hizo su padre: "ca su padre Guaynacapa le mandara al tiempo de su muerte, fuese amigo 
de las gentes blancas y barbudas que viniessen alli, porque hauia $n$ de ser señores de la tierra". Este pasaje forma parte de un contexto más extenso en el que Gómara refiere la conversación entre Huáscar y Hernando de Soto (junto con Pedro del Barco) en el Cuzco. Garcilaso en $C R$, lib. IX, cap. 15, cita textualmente del libro de Gómara una porción mayor que la que aquí se ha reproducido. Dos centímetros más abajo de la apostilla aparece la indicación "nota", referida a la última parte del cap. 115, en la que se trata del falso dolor de Atahualpa por la presunta muerte de Huascar, que todavía no había ordenado hasta ver la reacción de los españoles. En HPerú, lib. I, cap. 33, Garcilaso trata este episodio pero pone una cita textual de Zárate (y no de este pasaje de Gómara) al respecto. En cuanto a la reconstrucción del nombre del penúltimo inca, $[\mathrm{h}]$ tiene como alternativa $[\mathrm{g}]$. En efecto, en la dedicatoria a Felipe II de los Diálogos de amor, de 1586, Garcilaso escribe Guayna; hacia 1596, en la Relación de la descendencia... (cf. nota 11), prefiere Huayna (cf. Durand, op. cit., p. 287, n. 14).

34) Fol. LIVv, cap. 118, margen izquierdo central e inferior.

[...]Piçarro // [...] Espa ña $<$ S $>$

[vini] eronse a espa//[ña] [e]ntonces LX $[\mathrm{X}] / /$ [conq] uistadores // [de] [1] os quales El que menos truxo // [X]LM ducados y En ellos // [...] El capitan [...] // [tru]xo mas de CXXM duca$d o s / /[y]$ asi fue despue[s] // [al] [desc]ubrimjento y conquista $/ /[$ de $]$ la florida $<\mathrm{S}>$

Comentario. Reúno dos apostillas temáticamente afines, separadas por unos dos centímetros. No me está claro si forman parte de una sola, de la cual falta la parte intermedia. Ambas se refieren a la repartición del tesoro de Atahualpa, que es el tema del capítulo respectivo del texto de Gómara, y a la ida de Hernando Pizarro y otros conquistadores a España. La primera es de muy difícil reconstrucción y sólo se leen claramente las palabras transcritas. La segunda se inicia debajo de una línea en la cual aparece el subrayado que se indica a continuación: "Embio Piçarro el quinto y relacion de todo al Emperador con Fernando Piçarro // su hermano: con el se vinieron a España muchos soldados ricos, de veynte, treynta y quarenta // mil ducados". La apostilla, como resulta claro, aporta precisiones nu- 
méricas e introduce una obvia referencia a Hernando de Soto, cuyo nombre, sin embargo, no se ha conservado. En la referencia al número de personas que fueron a España con Hernando Pizarro se nota un resto de letra, que puede corresponder a $\mathrm{X}$ (de hecho, en Florida, libro I, cap. 1, Garcilaso habla de setenta conquistadores, pero en HPerú, lib. I, cap. 25 dice que fueron sesenta; respecto de la cantidad llevada por Soto se refiere en Florida, loc. cit., a "mas de cien mil ducados"). Igualmente, en la primera mención de cantidad de ducados parece haber un resto de $\mathrm{X}$ ante la L. Llamo la atención sobre que, en la transcripción de la apostilla, $\mathrm{M}$ corresponde al signo de mil.

35) Fol. LVr, cap. 120, a continuación de la última línea del capítulo.

Sin lo que tenja en chile

Comentario. Las dos últimas frases del capítulo dicen lo siguiente, a propósito de Huayna Capac: "Murio en Quito, dexo aquella tierra a Atabalipa, y el imperio y tesoros del Cuzco a Guaxcar. Tuuo (a lo que dizen) dozientos hijos en diuersas mugeres, y ochocientas leguas de señorio". A continuación viene la anotación, que parece referirse a la extensión del Tahuantinsuyo al morir Huayna Capac. En $C R$, lib. IX, cap. 15, Garcilaso concuerda con Gómara y añade un matiz: "dexó más de dozientos hijos e hijas, y más de trecientos, según afirmavan algunos Incas por encarescer la crueldad de Atahuallpa, que los mató casi todos".

36) Fol. LVv, cap. 121, margen izquierdo superior.

$[\mathrm{t}] \operatorname{esoros}<\mathrm{G}>$

Comentario. Se trata del capítulo titulado "De la magestad y riqueza de Guaynacapa, y costumbres de su corte y tierra". La apostilla tiene carácter resumidor del tema del capítulo. Garcilaso cita una buena parte de él en $C R$, lib. VI, cap. 2, y luego añade algunas precisiones acerca de los vergeles que los Incas tenían en todas las casas reales. 
37) Fol. LVv, cap. 122, margen izquierdo inferior y margen inferior.

$<$ extensa laguna en el margen izquierdo> quando lo dezian de todo El nuevo mundo y asi lo // [diz?] en confuso sin particularizar quales costumbres y cerimonjas eran [...] // y quales no y asi Es lastima leer Esta historia del piru // [...] [a]cabada asi En las hazañas que los Españoles hizieron e $n$ ella como // <...laguna de una línea por refilado $><P B: \mathrm{S}\rangle$

Comentario. Esta apostilla, suscitada por el capítulo que Gómara dedica a la "religion y dioses de los Ingas y otras gentes, y de sus idolatrias, supersticiones y sacerdotes", se inicia en el margen izquierdo y continúa en el inferior. El margen izquierdo está muy deteriorado y ha sido restaurado con un pegote que continúa hasta el margen inferior. Debajo del pegote se observa el original deteriorado y algunas letras y palabras breves que no permiten una reconstrucción textual. Fac., sobre la base de estos restos, ofrece unos fragmentos reescritos que no reflejan la anotación original. $P B$ atribuye la apostilla a Silvestre. El asunto es discutible. En todo caso, en la página siguiente hay otras dos largas apostillas que son de Garcilaso y que presentan una letra diferente a la que ahora está bajo consideración. Sin embargo, temáticamente las apostillas de estas dos páginas, fols. LVv y LVIr, forman una unidad. La que ahora examinamos constituye, a juzgar por la parte conservada, una recusación de la versión que da Gómara sobre la religión incaica. Lo que el anotador reprueba, como se ha visto, es el carácter confuso y "sin particularizar". Justamente es esto lo que objeta Garcilaso en varios capítulos de $C R$, especialmente lib. I, caps. 9 y 10 y lib. II, caps. 4 y 5. Así, Garcilaso atribuye la cantidad y variedad de dioses a los indios de la "primera edad", distinguiendo inclusive entre ellos, pues también hubo los que escogieron sus dioses "con alguna más consideracion" ( $C R$, lib. I, cap. 10). De tal manera que los españoles, "aplican otros muchos dioses a los Incas, por no saber dividir los tiempos y las idolatrías de aquella primera edad y las de la segunda. Y también por no saber la propriedad del lenguaje..." ( $C R$, lib. II, cap. 4). A este asunto de la "propriedad del lenguaje" se referirá justamente el Inca en las dos apostillas siguientes del fol. LVI. Como se verá, hay una estrecha relación entre la presente apostilla y las dos subsiguientes: todas, por lo demás, han dejado un fuerte eco en la redacción de los Comentarios. 
38) Fol. LVIr, cap. 122, margen superior, margen derecho y entrelineas.

entender bien la pronunciacion//y por ella la significacion de muchos vocablos de la len[gua] [general?] [que] [los] [In]gas Reyes del Piru mandauan hablar en todo su imperio escriue cossas muy agenas dela significacion del vo[ca]blo que expone y por tanto muy lejos de la verdad, como es en la significacion de estos nombres guacha o, guaca para lo qual es de saber que aunque en las letras parecen vno mismo difieren en la pronunciacion y por ella e[n] [la] significacion: quel vn nombre que significa Idolo se pronuncia la postrera silaba hiriendo con la lengua en el paladar, que [pues] que no tenemos [le] tras en la le[ngua] española $\mathrm{co}[\mathrm{mo}]$ hazer las $\mathrm{t}[\mathrm{ales}]$ pronunciaciones me parecio compararlas a las [que] hazen la vrraca y el cueruo en sus graznidos: que la vrraca pronuncia afuera en el paladar: y el cueru[o] dentro en las fauc[es] pues pronunciando como la vrraca sin [...] ydolo. y pronunciando como el cueru[o] significa [llo]rar. ay [...] que del nombre c [on] [que] los Indios [del] piru no[mbran] al Idolo [no] [se] puede $\mathrm{d}[\mathrm{edu}]$ zir el v[erbo] idolatra[r] [por]que es nombre $\mathrm{p}$ [ropio] para tod[os] [los] diosses [...] como el [que] otros [tienen] para ll[amar] a Dios [...] y esto d[e] [las] pronunc[iaci] ones no [se] puede $\mathrm{d}[\mathrm{ar}][\mathrm{a}]$ entender bien sino es viva voce. $y$ aun ha de ser por indi\{di\}o nat[ural] del Cuzco elegante y curioso en su lengua general. y Dios nos de su gracia y algunos $\mathrm{a}$ [ños] [de] vida: para que con $\mathrm{s}[\mathrm{u}]$ [fa]uor enmendemos muchos yerros que ay en esta histori[a] princip[almente] en las c[ostum] bres de [los] [na]turales [de] [la] tierra y [seño]res de$11[\mathrm{a}]<\mathrm{G}>$

Comentario. Esta extensa apostilla remite al ya señalado capítulo de Gómara y, particularmente, a la explicación -que aparece con subrayado- dada por el cronista español de la palabra "guaca": "Entran en sus te mplos llorando y guayando, que guaca esso quiere dezir". La primera línea y parte de la segunda se han perdido por refilado. En la primera línea conservada después de "pronunciacion" hay doble barra que señala el lugar de un añadido, el cual está en letra más pequeña y se lee sólo parcialmente, pues ha desaparecido por refilado: lo que se lee es "era" y luego "segu", fragmentos que pueden corresponder a "[verdad]era [y] segu[n]" (en Fac. aparece por repasado de letras "era logis"). En la transcripción no indico la división por líneas, a fin de no crear confusiones con el único caso de doble barra, que es el indicado y proviene del original. Esta anotación es sin duda el germen de varios capítulos del libro II de 
los Comentarios (que aquí, tanto como en 27, se preven), en los que el autor discurre, como se ha visto, sobre religión incaica, incidiendo asimismo sobre las cuestiones lingüísticas relativas a las palabras aquí explicadas. También en los Comentarios se insiste en lo que hoy llamaríamos la diferenciación fonológica de 'pares mínimos' como el expuesto. Pero la comparación algo jocosa con los gritos de la urraca y del cuervo, especie de recurso extremo para explicar la diferencia entre una consonante velar glotalizada y otra postvelar no fue incluida en los Comentarios, donde Garcilaso intenta afinar un poco más la descripción fonético-articulatoria y hacerla más objetiva. En cambio, parece que el Inca quiso rescatar su observación final sobre que el aprendizaje de estas pronunciaciones extrañas a oídos españoles requería ser hecha de viva voz y por "indio natural del Cuzco elegante y curioso en su lengua natural", pues en el lib. II, cap. 5, se pone como protagonista de la demostración con la siguiente anécdota (que cito por la ed. princeps, resolviendo las abreviaturas):

Acaescio que un dia, hablando de aquel lenguage, y de las muchas y diferentes significaciones, que vnos mismos vocablos tienen, di por exemplo este nombre Pacha, que pronunciado llanamente como suenan las letras Españolas, quiere dezir mundo vniuerso, y tambien significa el cielo, y la tierra, y el infierno, y qualquiera suelo; dixo entonces el Frayle, pues tambien significa ropa de vestir, y el axuar y muebles de casa. Yo dixe es verdad, pero digame vuestra paternidad que diferencia ay en la pronunciacion para que signifique esso? Dixome no la se. Respondile, auiendo sido maestro en la lengua iñora esto? pues sepa que para que signifique axuar, o ropa de vestir han de pronunciar la primera silaba, apretando los labios, y rompiendolos con el ayre de la voz, de manera que suene el romperlos; y le mostre la pronunciacion deste nombre, y de otros viua voce, que de otra manera no se puede enseñar. De lo qual el catredatico y los demas religiosos, que se hallaron a la platica se admiraron mucho.

39) Fol. LVIr y $v$, cap. 123, margen inferior del recto, y superior e izquierdo superior del verso.

Este nombre Lima con que en lengua de indios nombran a la ciudad de los Reyes, le corrompen lo[s] [es]pañoles en pronunciar le assi: que no se ha de pronunciar sino, Rimac, con .r. senzilla co[mo] [sue]le pronunciarse <entre líneas //la .r.//> en medio 
de la dicion, y no con .rr. duplicada, como pronuncian los españo[les] [al] principio de parte- y significa, el que habla: porque en este valle de Rimac, o delos Reyes, $\operatorname{co}[\ldots]<$... laguna de una línea al final del margen inferior del recto $><.$. laguna de una linea al inicio del margen superior del verso $>$ [don]de estava. El qual ydolo era, como el oraculo de Apolo en Delphos que dava respuestas a todo lo que le preguntavan. Y porque hablava el idolo o el demonio en el le llamauan Rimac/. Este con otros muchos idolos, que por la tierra auia que hablauan familiarissimamente con los indios, perdieron la habla, luego que los cristianos entraron en ella. Y se dixeron missas consagrando el cuerpo y sangre de nuestro señor Iessucristo. De lo qual se admiraron los indios principalmente de este rimac, que era el [sup] erior idolo de [tod] os los que davan [res]puestas y por [esto] [le] [1]lamauan el [que] [h] abla. Y de [aqu] i vinieron [los] indios del [pir] u a persuad[ir]se que pues sus [ido]los perdian [su] virtud era [me]jor y mas $\operatorname{ver}[\mathrm{da}]$ dera la ley $[\mathrm{de}]$ los cristia[no]s que la suya. $<\mathrm{G}>$

Comentario. Esta apostilla, como la anterior, parte de un comentario lingüístico, del cual se deriva la explicación de un fenómeno religioso, en este caso, de los ídolos habladores. $\mathrm{Su}$ origen está en una referencia de Gómara a Pachacámac, que aparece subrayado en el texto, como lo indico a continuación: "Era el te mplo de Pachacama, que cerca de Lima estaua, famosissimo en aquellas tierras, y muy visitado de todos por su deuocion y oraculos: ca el diablo aparecia y hablaua con los sacerdotes que alli morauan". La apostilla del Inca se concentra en la explicación fonética y semántica de Rímac para tratar el asunto religioso. Pero no se refiere a Pachacámac (salvo que lo hiciera en la líneas no conservadas). En cambio, al utilizar esta apostilla en los Comentarios recupera el punto de partida y aclara la relación entre Pachacámac y Rímac. En efecto, en el lib. VI, cap. 29, señala primero la relación geográfica entre Pachacámac y Rímac, y luego explica la semántica de este último nombre:

El valle de Rímac está a cuatro leguas al norte de Pachacámac. El nombre Rímac es participio de presente: quiere dezir el que habla. Llamaron assí al valle por un ídolo que en él huvo en figura de hombre, que hablava y respondía a lo que le preguntavan, como el oráculo de Apolo Délfico y otros muchos que huvo en la gentilidad antigua; y porque hablava, le llamavan el que habla, y también al valle donde estava 
Obsérvese que esta parte final de la cita sirve para reconstruir "donde", luego de la laguna de dos líneas en la apostilla. El parentesco con la apostilla es evidente; pero es evidente también que Garcilaso ha integrado una precisión gramatical ("es participio de presente") y que ha dejado de lado el aspecto fonético del nombre, que no aparece ya ni siquiera cuando se establece la identidad entre Lima y Rímac en el párrafo siguiente:

Este ídolo tuvieron los yuncas en mucha veneración, y también los Incas después que ganaron aquel hermoso valle, donde fundaron los españoles la ciudad que llaman de los Reyes, por haverse fundado el día de la aparición del Señor, cuando se mostró a la gentilidad. De manera que Rímac o Lima o la ciudad de los Reyes, todo es una misma cosa; tiene por armas tres coronas y una estrella.

Todavía, en el párrafo que sigue, hay una alusión implícita a la confusión de Gómara, pues en él se dice que

Los historiadores españoles confunden el templo de Rímac con el de Pachacámac y dizen que Pachacámac era el que hablava, y no hazen mención de Rímac; y este error, con otros muchos que en sus historias hay semejantes, nascen de no saber la propriedad de la lengua y de no dárseles mucho por la averiguación de las cosas, y también lo pudo causar la cercanía de los valles, que no hay más de cuatro leguas pequeñas del uno al otro, y ser ambos de un mismo señor.

En cuanto a la segunda parte (temáticamente hablando) de la apostilla, ella no pasó a los Comentarios (aparece desarrollada, en cambio, en HPerú, lib. I, caps. 29 y 30, titulado este último "Enmudecieron los demonios del Perú con los sacramentos de la Santa Madre Iglesia Romana"). El Inca debe de haber reconocido que su contenido - referido a la victoria del cristianismo sobre la idolatría- no era pertinente en el contexto de los capítulos respectivos de los Comentarios dedicados a Pachacútec, y concretamente a la conquista de Pachacámac y del valle del Rímac. En el cap. 31 del mismo libro VI de los Comentarios, en cambio, se abunda sobre el asunto de los ídolos y se señala que Pachacútec mandó echar a los ídolos del templo de Pachacámac, ya que siendo Pachacámac "hazedor o sustentador del universo, no era dezente que ídolos de menor majestad estuviessen en su templo y altar"; asimismo, se indica que, una vez 
sometido Cusimanco, rey del valle de Rímac, Pachacútec ordenó "que los Incas tuviessen en mucha estima y veneración al oráculo Rímac y mandassen a todos sus reinos hiziessen lo mismo". Finalmente, el Inca da cuenta de cómo el demonio, sabedor de que los ídolos habían desaparecido de Pachacámac, "quiso hazerse particular señor dél, pretendiendo que lo tuviessen por el señor no conoscido" y logró convertir el templo de Pachacámac en un centro de oráculos desde el cual él hablaba para los sacerdotes "de mayor dignididad y crédito", mientras el ídolo del Rímac lo reservó para los negocios "comunes y plebeyos": "y assí le confirmó aquel ídolo el nombre hablador, porque haviendo de responder a todos, le era forçoso hablar mucho". Con esto se vuelve, de modo aclaratorio, a la frase de Gómara que dio origen a la apostilla.

40) Fol. LVIv, cap. 124, margen izquierdo central.

$[$ Man] co Ynca $<\mathrm{G}>$

Comentario. La apostilla corresponde al lugar en el cual está mencionado "Mango hermano de Atabaliba". Obsérvese la graficación del antropónimo y del etnónimo con "c" y no con "g".

41) Fol. LVIv, cap. 124, margen izquierdo inferior

riqueza / / Cassamar $[\mathrm{ca}]<\mathrm{G}>$

Comentario. La apostilla se refiere al lugar en el cual Gómara habla de la riqueza que se obtuvo en el saqueo del Cuzco, mayor que la conseguida en Cajamarca (que él llama Caxamalca, según el uso de la mayoría de cronistas del xvi). Todo el contexto en el que se encuentra tal lugar aparece citado en HPerú, lib. II, cap. 7. La apostilla está incompleta, pues faltan algunas letras iniciales: quizá originariamente rezaba "mas riqueza que en Cassamarca" o, como dice el propio Garcilaso en el mencionado capítulo, luego de citar a Gómara y a Zárate, "tanta o más riqueza que en Cassamarca": "Con estas autoridades queda bastante provado lo que atrás diximos, que en el Cozco hallaron los españoles tanta y más riqueza que en Cassamarca". La forma del topónimo es la que usa Garcilaso en CR y en HPerú, y a partir de la cual, corrigiendo la 
de historiadores españoles, deriva la etimología: "Ha de dezir Cassamarca, que es tierra o provincia o barrio de yelo, porque cassa significa yelo, y marca tiene los otros tres significados" (HPerú, lib. I, cap. 33). En este caso, la corrección del Inca es injustificada, ya que la primera parte del topónimo contiene la palabra / kaša/ "espina", transcrita desde las primeras documentaciones como Caxa- (moderno Caja-).

42) Fol. LVIIr, cap. 125, margen superior.

Es falso que El comer la <...laguna de más de media línea> // [al$\mathrm{gu}]$ na vez por mucho gusto echan parte de las asaduras En mucha cantidad de agi // su pimiento que ellos tanto comen u otra carne hecha tasajos al sol y esto comen // mas por recreacion y deleyte que por costumbre y lo mismo ha/ / zen spañoles E ytalianos de las anchouas y salchichas y ahun de lonjas de jamon $<\mathrm{S}>$

Comentario. Esta es la primera de cuatro apostillas al capítulo titulado "De las calidades y costumbres del Cuzco" (cf. 43, 44 y 45). La que acabamos de transcribir se refiere a la afirmación de Gómara de que "Comen cruda la carne del pescado", la cual aparece subrayada en el texto. Es probable que la parte perdida de la primera línea rectificara este hecho general, pues la siguiente comienza ya con la explicación de los procedimientos ocasionales de maceración en ají y de secado al sol, indirectamente confirmados por Garcilaso, quien en $C R$, lib. IX, cap. 39, hace decir a su pariente el "Inca viejo", como expresión de odio hacia el hijo de Atahualpa: "Dénmelo assi muerto como está, que yo me lo comeré crudo, sin pimiento". $P B$ considera que la apostilla proviene de la mano de Silvestre. Lo mismo valdría para la segunda (43) y la tercera (44), que tienen letra casi igual. En cambio, la letra de la cuarta (45) es algo diferente. A diferencia de esta anotación gastronómica, las otras han tenido ecos más fuertes en los Comentarios.

43) Fol. LVIIr, cap. 125, margen izquierdo superior

Falso $<$ S? $>$

Comentario. Se refiere a la frase, que aparece subrayada en el ejemplar, "Heredan los sobrinos y no los hijos", a continuación 
de la cual Gómara precisa: "solamente heredan los Ingas a sus padres como mayorazgos". Ahora bien, la opinión de Garcilaso sobre el espinoso problema de la sucesión en el mundo andino, ampliamente expuesta en $C R$, lib. IV, cap. 10, es sustancialmente concordante con la de Gómara, ya que también, según ella, entre los incas la sucesión recaía en el mayor de los legítimos en sangre, mientras que entre los curacas hubo "diferentes costumbres". La letra de esta apostilla parece ser de Silvestre.

44) Fol. LVIIr, cap. 125, margen derecho (de través).

Es falso que bivos se dexan Enterrar de su propria voluntad por que dezian que le querian yr a seruir En la ot[ra] // vida como hazian aca que alcançaron Estos yndios la ynmortalidad del alma sino que entendian que biui[...] / / <laguna de un cuarto de línea $>$ esto les metian a los grandes señores toda su baxilla y vestidos de donde fueron despues <laguna de una línea, con restos de letras> $<\mathrm{S}$ ? $>$

Comentario. Cf. la apostilla siguiente.

45) Fol. LVIIr, cap. 125, margen izquierdo central.

resurreccion // inmortalidad $<\mathrm{G}$ ? $>$

Comentario. La apostilla 44 trata de costumbres funerarias de los incas, con el objeto de rectificar y precisar el siguiente pasaje de Gómara, del cual hay una porción subrayada que se indica: dentro de las tumbas "meten tambien algunas de sus amadas mugeres, pages, y otros criados que los siruan y acompañen: mas estos no van en carne, sino en madera". Parece que el mentís con el que se inicia dicha apostilla se refiere a la frase subrayada; luego, un que causal introduce la verdadera costumbre y precisa que en ella no había coacción. En esto hay plena concordancia con la explicación de Garcilaso en $C R$, lib. VI, cap. 5:

Cuando moría el Inca o algún curaca de los principales, se matavan y dexavan enterrar vivos los criados más favorecidos y las mujeres más queridas, diziendo que querían ir a servir a sus Reyes y 
señores a la otra vida; porque, como ya lo hemos dicho, tuvieron en su gentilidad que después de esta vida havía otra semejante a ella, corporal y no espiritual. Ofrecíanse ellos mismos a la muerte o se la tomavan con las manos, por el amor que a sus señores tenían. Y lo que dizen algunos historiadores <Acosta, lib. V, cap. 7 , que los matavan para enterrarlos con sus amos o maridos, es falso...

Lo cierto es que ellos mismos se ofrecían a la muerte... ${ }^{26}$.

En la apostila 44, además, se menciona de modo explícito la creencia en la inmortalidad del alma. La 45 señala que justamente Gómara alude a que los incas creían en la "resurrecion delos cuerpos, y la inmortalidad de las almas". Ahora bien: en los Comentarios, Garcilaso dedica un capítulo entero, el 7 del libro II, a explicar que los incas "Alcançaron la inmortalidad del ánima y la resurrección universal". En dicho capítulo se menciona en apoyo de esta atribución de creencias, además de Gómara, de quien se cita un pasaje, a Zárate y Cieza, y se dice: "Estas autoridades y la de Gómara hallé leyendo estos autores después de haver escrito yo lo que en este particular tuvieron mis parientes en su gentilidad". Y poco después añade el Inca: "Y certifico que los hallé después de haver escrito yo...". Ahora bien, esta repetida y enfática declaración no deja de causar cierta perplejidad. Tomando al autor al pie de la letra, habría que postular una antigua versión preliminar de este capítulo, del todo anterior a sus lecturas sobre historia peruana. Si esto es así, dicha versión pudo haber sido la que, originariamente se insertó en Florida, de donde hubo de ser sacada luego, como explica Garcilaso aquí mismo, por "ciertas causas tiránicas”, para ser vuelta a poner "en su lugar" (lo cual supone una versión ya avanzada de $C R$ ). Y probablemente esa versión incluida en Florida no contenía las referencias a las fuentes confirmatorias. El asunto, que implica el problema de los estratos textuales que se pueden reconocer en los Comentarios, es complejo y no puedo desarrollarlo en esta ocasión.

26 Para evaluar el punto de vista de Garcilaso en el marco de las informaciones sobre las costumbres funerarias de los Incas puede verse C. ARANíBAR, "Notas sobre la necropompa entre los incas", Revista del Museo Nacional, 36 (1969-70), 108-142, y, más recientemente, F. Kauffmann Doig, "Ultratumba entre los antiguos peruanos", en Homenaje a Don Aurelio Miró Quesada Sosa, ed. H. López Martínez, pp. 215-232. 
46) Fol. LVIIr, cap. 126, margen izquierdo inferior.

Acuden // muchos // Españoles $<\mathrm{G}>$

Comentario. Repite, en modo resumidor, la indicación de Gómara, en el capítulo "De la conquista de Quito", de que "Acudian al Peru con la fama del oro tantos españoles, que ayna se despoblaran Panama, Nicaragua, Quauhtemallan, Cartagena, y otros pueblos e islas". Exactamente esta frase, a la que remite la apostilla, es la que cita Garcilaso en HPerú, lib. II, cap. 1. Recuérdese que se trata del contexto de la llegada del padre de Garcilaso al Perú.

47) Fol. LVIIv, cap. 126, margen derecho superior y margen superior.

A las monjas // vestales $<\mathrm{G}>$

$<$ laguna de una línea alegrareis que traen cassas hechas en que meten sus genitales entendiendo por las brague//tas, ellas se rieron del disparate y les costo caro que las enterro vivas En un arroyo hondo que // auia entre dos sierras echando selas a $m$ bas encima $<\mathrm{G}>$

Comentario. Reúno estas dos anotaciones que forman parte de la misma anécdota. Garcilaso da una versión un tanto diferente de la de Gómara (a quien alude sin mencionar, al igual que a otro "historiador"). Este dice, en efecto, al final del capítulo sobre la conquista de Quito: "Dixo Ruminaguy a sus mugeres, alegraos queya vienen los christianos con quien os podreys holgar. Rieronse algunas como mugeres, no pensando quiça mal ninguno. El entonces degollo las risueñas...”. A la derecha del subrayado Garcilaso ha escrito la primera anotación precisadora. Luego, en el margen superior proporciona su versión, la cual aparece más extensa y elaborada en HPerú, lib. II, cap. 4.

48) Fol. LVIIv, cap. 127, margen derecho central.

Año de / / 1535 // paso alva / / rado al / / piru <G? $>$

Comentario. El capítulo de Gómara trata de la expedición de Pedro de Alvarado; la anotación está ubicada hacia la mitad del 
capítulo, que Garcilaso cita casi íntegramente (exceptuando las dos frases finales) en HPerú, lib. II, cap. 2. Dichas frases finales (que reproduzco en el Comentario sucesivo) fueron materia de la apostilla 49.

49) Fol. LVIIv, cap. 127. En la entrelínea, al final de la última línea del capítulo.

Pues ni son Iudios ni moros sino gentiles.<testado lo que sigue $>$ mal que os pese a vos / / y a quien os dio la relacion $<\mathrm{G}$ ? $><P B$ :G $>$

Comentario. $P B$ lee: "mal que le pese al autor y a quien le dio la relacion”. La apostilla rectifica a Gómara, quien al final del capítulo dice, con referencia a los indios encontrados por Alvarado en el camino de la costa hacia Quito: "Hallaron muchas esmeraldas, y muchos hombres sacrificados: ca son los de alli muy crueles idolatras. Viven como sodomitas, hablan como moros y parecen judios". Según $P B$, quien leyó la parte testada (aunque de modo algo diferente, como se ha visto), es anotación de Garcilaso. Por la letra es posible; haya sido de él, o de otra mano, es claro el intento (probablemente de Garcilaso, quien en otra ocasión procede explícitamente del mismo modo, cf. 74) de suprimir una frase agresiva en contra del autor y de su informante, agravada por el tratamiento de "vos". En Fac. la "u" de Iudios ha sido repasada, con el resultado de que se lee Indios (!).

50) Fol. LVIIv, cap. 128, margen izquierdo inferior.

[pau]llu Ynca $<\mathrm{G}>$

Comentario. La apostilla pone de relieve la mención del hijo de Huayna Capac (llamado Paulo por Gómara), elegido como inca por Quizquiz, general de Atahualpa. Garcilaso se refiere a la elección de Paullu en HPerú, lib. I, cap. 39. Con respecto al nombre cf. CR, lib. VI, cap. 2: "El Inca que <Cieza $>$ llama Paulo se dezía Paullu, de quien hazen mención todos los historiadores españoles...”. 
51) Fol. LVIIv, cap. 128, margen izquierdo inferior.

[ped] ro de // [alva]rado // [en?] [p]uerto viejo $<\mathrm{G}>$

Comentario. La apostilla se refiere a la llegada de Pedro de Alvarado. Cf. HPerú, lib. II, cap. 2, en el que el Inca combina noticias de Gómara y de Zárate sobre dicha expedición. Por refilado se han perdido algunas letras, como también en la apostilla anterior. En cambio, el refilado no ha afectado la parte izquierda de la segunda de las apostillas reunidas en 47 , que comienza un poco más a la derecha.

52) Fol. LVIIIr, cap. 128, margen izquierdo superior.

Cupay $\mathrm{Yu} / /$ panqui $<\mathrm{G}>$

Comentario. Corrección de "señor Zopoçopaguy" que consigna Gómara como nombre de uno de los capitanes de Atahualpa con el que los españoles de Alvarado tuvieron que enfrentarse en Quito. Garcilaso en HPerú, lib. II, cap. 9, trata ampliamente de este capitán y justamente señala el error de Gómara, y también el de Zárate, en sus respectivas versiones del nombre, luego de lo cual aclara la etimología y la motivación semántica de éste en su forma correcta.

53) Fol. LVIIIr, cap. 128. Entrelínea al final del capitulo y margen derecho.

Por Este concierto llamauan despues a los que pasaron con aluarado lo[s] / / vendidos $<$ de que testado $>$ y comprados de que ellos $<$ mucho testado $>$ se corrian mucho/ $<P B: \mathrm{G}>$

Comentario. La apostilla se refiere al concierto entre Almagro y Alvarado, según el cual éste se comprometía a abandonar su empresa descubridora y conquistadora, y a entregar su flota a Pizarro y Almagro por cien mil pesos de oro. Según $P B$ es de Garcilaso. La letra permite dudarlo; por lo demás, la ortografía no parece de Garcilaso, quien es cuidadoso en el uso de la "ss", que aquí no se respeta ("pasaron”). Por otro lado, no le sería éste un comentario particularmente grato, visto que su padre llegó al Perú como "vendido". 
54) Fol. LIXv, cap. 130, margen derecho superior.

Dio piçarro [a pedro] // de alvarado [los] // cjen mill pesos [del] [con]//cierto y otro[s] [vein]//te mjll de ay[uda] // de costa sin [otras?] // muchas joja[s] [y] // preseas

Comentario. La apostilla completa la información de Gómara y ratifica el cumplimiento, por parte de Pizarro, del compromiso con Alvarado. Se han perdido letras por el refilado; la reconstrucción se hace con ayuda de HPerú, lib. II, cap. 15, donde Garcilaso retoma casi literalmente el texto de la apostilla: "Al fin dellos dio el Don Francisco Piçarro a Don Pedro de Alvarado los cien mil pessos de oro del concierto, y otros veinte mil pessos de ayuda de costa, y muchas esmeraldas, turquesas...".

55) Fol. LIXv, margen superior, izquierdo e inferior, y folio LXr, cap. 135, margen inferior e izquierdo inferior (y cf. el Comentario para un resto de apostilla en el fol. LXr, margen superior).

[lo que sigue hasta el siguiente corchete es texto de los CR, cf. infra: En todo lo que el Autor escriuio del Cuzco, y de Chile ay mucho que quitar, y que añadir: porque según lo que aquí dize, paresce que] lo Escriuió por relacion de algunos que inorauan el hecho tanto como el porque [asi?] lo muestran En este paso por que la que lo que $<$ sic $>$ pasa de la verdad es esto.// almagro no boluio de Chile por El camino que fue a la yda que fue por la sierra con mucha guerra y hambre y al pasar de los puertos para Entrar En copayapo que Es El primer valle de chile por aquel camjno cayo tanta nieue y hizo tan grandes frios que se elo mucha de su gente y cauallos y muchos Escapa[ron] con los de[dos] de los pies cay[dos] elados de frio [as]i de negros co[mo] [de] yndios y spaño[les]/. dende a [cu]atro meses lle[ga]ron al mismo [p]aso ruy dias [y] [j] uan de herra[da] con la gente que auian quedado hazien[do] en El piru por orden [de] almagro El qual paso [se] tarda En pasar [c] uatro // <interlineado y cinco > dias/ donde se halla[ro]n muy faltos [de] comida a ca[u]sa de auerla [al]çado los yndios [ha]llaron los [pu] ertos con me[n] os nieve pasa[ro]nlos con mejor [tie]mpo reme[d]iaron su ham[br]e con los $\mathrm{ca}[\mathrm{u}]$ allos que ha[lla]ron elados [y] tan frescos [co]mo dize la $[\mathrm{h}]$ istoria - $[\mathrm{g}]$ eronimo de [a]lderete que [fu]e gouernador de Chile muchos años despues [vie]ndo los puertos con [po]ca nieue Estando En [cop]ayapo quiso yr y otros [m] uchos con el a 
uer si auia alguna señal [o] [r]astro de a[que]lla mortan[dad] tan memo[ra]nda: que su[ce]dio quando los [pas]o almagro [h]allaron vn [neg]ro arrima[do] a las peñas [y] En pie sin [au] erse caydo [y] [vn] cauallo [tam] bien En pie [co]mo si fuera [de] palo y las [rie]ndas en las [ma] nos del negro [ya] [p]odridas y [esto] fue des[pues] [de] cinco o seis [años] [q]ue fue bal[di]via por gouer[nad] or a quien sucedio alderete almagro como Esta dicho no boluio por El camino de la sierra que lleuo sino por El que aora se anda que Es por la costa de la mar que por otro nombre se llama los llanos ay vn despoblado desde atacama que Es El postrer pueblo del piru hasta copayapo que Es El primero de chile de ochenta leguas/ ay por El camjno algunos manaderos de agua que no corre de cuya causa siempre huele mal y por el poco vso que ay de sacalla y $<$ tachado de $>$ estos son a trechos a siete leguas y a mas y a menos y por la poca agua que tenjan por no auer recaudo para todo El exerçito [laguna de parte de penúltima línea; se reconstruye con $C R$ mando almagro que començasen a pasar] el despoblado los de a cauallo [en quadrillas de cinco] [laguna de la última línea; se reconstruye con CR en cinco y de seys en seys y como los delanteros iuan limpiando los pozos acudia mas agua de manera que pudieron yr] creciendo El $\mathrm{n} u$ mero hasta que paso todo El exercito/ embarcose almagro pasado El despobla[do] En un nauio que auia traydo noguerol de ulloa capitan del/ Este era hijo del alcayde de sjmancas que mato El obispo de çamora $<\mathrm{S}>$

Comentario. La apostilla constituye la parte sustancial de la abundante intervención manuscrita en los márgenes de dos páginas del libro de Gómara. Consiste, como se ha comprobado, en un largo texto, el cual se inicia en el margen superior de LIXv, continúa en el margen izquierdo e inferior, y pasa luego al margen inferior del folio siguiente. Por refilado se han perdido al menos dos líneas del inicio (quedan restos pequeños de tinta), algunas letras del inicio de lo escrito sobre el margen izquierdo y casi dos líneas al final de lo escrito en el margen inferior. En la parte superior izquierda hay un resto (que no edito aparte y que no sale en Fac. sino como restos de tinta) de una anotación, sin duda de Garcilaso, que identifica la apostilla como del "conquistador", al que se ha referido en ocasiones anteriores. En efecto, allí se lee claramente "[tod]o esto es del", referencia que seguramente terminaba con [el conquistador viejo] o con [el conquistador del Peru] o quizá con [el conquistador antiguo], que es lo que dice Garcilaso en HPerú, como se verá a continuación. 
La apostilla del conquistador se refiere a la expedición de Almagro a Chile, especialmente a la vuelta, en la cual sufrió "muchos trabajos", al punto, dice Gómara en su libro, que "comio los cauallos que se le murieron ala yda, cosa bien de notar: porque al cabo de quatro meses, o mas tiempo, estaua $n$ por corromper, y tan frescos (segun dizen) como rezien muertos. Estauanse tambien los Españoles arrimados a las peñas...”. Toda esta última cita hasta "arrimados", donde cambia la página, ha sido subrayada; sobre el margen izquierdo, por lo demás, y a la altura del subrayado, hay un asterisco y encima de él restos de letras, entre los cuales se reconocen, con bastante claridad, los de una "f" y una "l". Así, lo que habrá estado originariamente era: "falso". En efecto, la apostilla constituye la versión que da el conquistador sobre la expedición a Chile. También en el margen superior del fol. LXr hay un resto de apostilla que parece referirse al mismo contexto y de la cual se puede leer sólo "sobre este... como en las particularidades de ella". Ahora bien, la identificación de la autoría de la apostilla recibe una confirmación del propio Garcilaso, quien en HPerú, lib. II, cap. 21, la cita, introduciéndola de este modo:

Por todo lo cual <i.e., por la confusa relación de Zárate y Gómara sobre la jornada de Chile s aquel conquistador antiguo de quien hemos hecho mención en otra parte, que marginó la Historia de Gómara, viendo en este passo la confusa relación que al autor hizieron, como enojado della, dize sobre el capitulo ciento y treinta y cinco lo que se sigue:

Luego viene la anotación, que se ha transcrito arriba, del conquistador. Sin embargo, la cita, anunciada como discurso directo, no es literal: Garcilaso reordena la secuencia del texto, de tal modo que la parte que se inicia con "Almagro como está dicho" y termina con "que el Obispo de Çamora mató", la cual constituye el final de la anotación del conquistador aunque con el verbo antepuesto, pasa a estar antes de la que se inicia con "Gerónimo de Alderete" y culmina con "a quien sucedió Alderete". Esta reordenación, así como otras mejoras que introduce el Inca, le dan al texto una mayor coherencia y convierten la defectuosa glosa del conquistador en una pieza compatible con el contexto estilístico en el cual se introduce. Las mejoras aludidas se dan en el terreno de la ortografía, la sintaxis y el estilo: supresiones, cambios de palabras, cambios 
de orden, pequeños añadidos, todo ello sin que se altere el sentido fundamental del texto citado, aunque sí su literalidad. Por consiguiente, la cita de Garcilaso sirve para reconstruir en las partes faltantes la apostilla bajo consideración.

56) Fol. LXIr, cap. 137, margen derecho superior.

Salio al so[co]//rro Garcila[sso] // de la Vega c[on] // CL españ [oles] // que estauan e[n] [la] // conquista [de] [la] // Baya de $S[\mathrm{an}] / /$ [Ma] teo

Comentario. Se trata de una apostilla al margen del capítulo "Del socorro que vino de muchas partes a Francisco Piçarro" cuando estaba amenazado por los indios en Lima. Garcilaso completa la información del texto, poniendo en lugar central a su padre; y en HPerú, lib. II, cap. 22, luego de dar cuenta de lo que dice la apostilla, narra extensamente las peripecias de la empresa de San Mateo y Buenaventura.

57) Fol. LXIr, cap. 138, margen derecho inferior.

Por este [agra]//uio se pas[so] // despues a l[os] [al]//magros y [fue?] // contra los [pi] // [ça] rros

Comentario. La apostilla se refiere a la noticia de que, cuando llegó a Lima Alonso de Alvarado (quien se encontraba empeñado en la conquista de los Chachapoyas) para socorrer a Pizarro, éste lo nombró su capitán general, en reemplazo de Pedro de Lerma, "el qual lo tuuo a deshonra". Se retoma en HPerú, lib. II, caps. 33 y 34: en este último -en el que, por lo demás, se citan varios pasajes de Gómara- se sigue de cerca la huella de la apostilla, como se puede ver por el siguiente fragmento: "Estando Almagro rodeado destas congojas y temores, no sabiendo a qué parte echar, tuvo cartas del capitán Pedro de Lerma; el cual, sintiéndose agraviado del Marqués por lo que atrás diximos, y viendo la ocasión presente para poderse vengar...”. 
58) Fol. LXIr, cap. 138, margen derecho inferior.

Yndios $[\mathrm{ami}] / /$ gos mue[ren]

Comentario. La apostilla pone de relieve la noticia de Gómara sobre la muerte de españoles e indios amigos que formaban parte de la hueste de Alonso de Alvarado en ocasión de la batalla de Lumichaca. Todo el pasaje, dentro del cual se encuentra la referencia a los indios amigos, fue citado en HPerú, lib. II, cap. 33 .

59) Fol. LXIr, cap. 138, margen izquierdo inferior.

Titu yu//panqui

Comentario. La apostilla corrige el nombre de un capitán de Manco Inca señalado por Gómara como "Tizoyo", el cual se enfrentó a las tropas de Alonso de Alvarado cerca de Pachacámac, en el contexto de la rebelión de Manco Inca. Garcilaso da cuenta de esta batalla en HPerú, lib. II, cap. 33; en el cap. 38 menciona a Titu Yupanqui (corrigiendo a Gómara y también a Zárate, pues este último dice "Tiço Yopangue") a propósito de otra de las incidencias de la rebelión.

60) Fol. LXIIIr, cap. 141, margen derecho central e inferior y margen izquierdo inferior.

Francisco // Bara[hona] // compa[ñero] [de] // Hernando [Piça]//rro [...] // Orgoñ [ez] [...] // Pedro de [Lerma] // $<$ varios niveles con restos de palabras no interpretables como texto> Sa$\mathrm{m}$ [aniego]

capitanes muertos

Comentario. El capítulo de Gómara relata la batalla de Las Salinas. Se trata de dos apostillas estrechamente relacionadas. La primera, en el margen derecho, está muy mal conservada: parece agregar algunos particulares, tal vez que Francisco de Barahona fue muerto por Orgóñez, o que Pedro de Lerma fue herido en batalla y luego asesinado en su casa por Juan de Samaniego. Todo esto se narra en HPerú, lib. II, caps. 37 y 38. Este 
último capítulo se inicia justamente con la cita textual de la parte final del capítulo de Gómara, parte que da pie a la apostilla. La segunda apostilla, en el margen izquierdo, se refiere a otros capitanes muertos en batalla y mencionados por Gómara.

61) Fol. LXIIIv, cap. 143, margen izquierdo inferior.

Alvara[do] // <siguen palabras y restos de palabras en diversos niveles; no reconstruibles en texto $>$ encon // de // pesos de // leua // Cuzco // de ynca ////omo////si////rien////sus

Comentario. Apostilla deturpada. Se encuentra al margen del capítulo dedicado al ajusticiamento de Diego de Almagro después de Las Salinas, capítulo íntegramente citado por Garcilaso en HPerú, lib. II, cap. 39. Sin embargo, no hay elementos suficientes para una reconstrucción textual. Se inicia, al parecer, con una referencia a Diego de Alvarado, secuaz de Almagro, quien había intercedido por Hernando Pizarro cuando éste estaba preso y condenado a muerte por Almagro, sin que esto le sirviera luego para salvar del ajusticiamiento a su caudillo. Regresó a España, dice Gómara, para querellarse, ante el Emperador, de los Pizarro, y murió allí, envenenado, según algunos. Sin embargo, el resto, que está separado por un blanco, podría referirse a Almagro, de quien se habla en el texto de Gómara a continuación de Alvarado, sobre todo teniendo en cuenta que hay un subrayado (que no se nota en Fac. y que aquí pongo en evidencia) en la línea que corresponde al primer resto apostillado ("encon"), y que dicho subrayado se refiere a la generosidad de Almagro con quienes lo acompañaron en la expedición a Chile. El pasaje de Gómara dice lo siguiente: "Perdono mas de cien mil ducados, rompiendo las obligaciones y conocimientos alos que fueron con el al Chile, liberalidad de principe, mas que de soldado: pero quando murio, no tuuo quie $n$ pusiesse un paño en su degolladero". Por lo demás, Garcilaso en HPerú, lib. II, cap. 20, reproduce literalmente la segunda parte de este paso (a partir de "liberalidad", independizándolo de lo anterior por medio de la anteposición de "Fue"). Podría tratarse de dos apostillas diferentes. 
62) Fol. LXIVr, cap. 144, margen derecho superior.

Diuid[ense] // los capitanes [para] // nueua[s] [con]//quista[s]

Comentario. La apostilla se refiere a las nuevas entradas conquistadoras que se emprendieron, según relata Gómara, luego de la muerte de Almagro. En HPerú, lib. II, cap. 40, Garcilaso desarrolla este tema y cita por extenso del presente capítulo de la obra del soriano.

63) Fol. LXVr, cap. 145, margen derecho superior.

Este secretario [hizo?] // en aque[lla] [coyun?]//tura un [malfecho?] // por mand[ar] // vna letra [...] // para los [de] [Chi] $/ /$ le/. por [lo cual?] // como des[...]//dos hiz[...] // hizieron $[\ldots] / /$ ando el $[\ldots] / /[$ des $]$ esperaci $[$ on $]<\mathrm{G}$ ? $>$

Comentario. La apostilla se refiere a Antonio Picado, secretario de Pizarro, mencionado por Gómara, a raíz de las circunstancias previas al asesinato del Marqués por los almagristas, del cual trata Gómara en este capítulo. Está muy deteriorada por el refilado que ha hecho desaparecer varias letras. Como Garcilaso en HPerú, lib. III, cap. 6, relata con detalle esta anécdota, queda claro el sentido general de la anotación; asimismo, el texto de la HPerú sirve para reconstruir algunos particulares de la apostilla, si bien no la totalidad. El pasaje en cuestión es el siguiente:

Esta remisión de los de Almagro trocó en cólera, ira y saña un malhecho que Antonio Picado, secretario del Marqués, hizo en aquellos días; y fue que, como los de Chilli huviessen puesto las sogas en la picota, como atrás se dixo, que la una de ellas le amenazava, y anduviessen tan desvergonçados y descomedidos contra el Marqués, y que por otra parte no eran más que amenazas y blasonar del arnés sin curar de vestirlo (motejándoles de esta covardía), sacó puesta en la gorra una medalla de oro muy rica, esmaltada en ella una higa, con una letra que dezía: "Para los de Chilli". De lo cual se afrentaron e indignaron tanto aquellos bravos soldados, que determinaron executar la muerte del Marqués sin aguardar la llegada del juez. 
64) Fol. LXVr, cap. 145, margen derecho inferior.

Diego $[$ Men $] / /$ dez

Comentario. La apostilla pone de relieve uno de los once nombres, señalados por Gómara, de los almagristas asesinos de Pizarro capitaneados por Juan de Rada. Cf. también la apostilla 71 para otra mención de Diego Méndez. Vale la pena señalar que el Inca en HPerú, lib. III, cap. 6 repite en la misma forma (es decir en algunos casos nombre y apellido, en otros sólo apellido) las listas de Gómara, pero agrega un nombre más que Gómara no menciona, señalando explícitamente esta ausencia en la obra del clérigo soriano.

65) Fol. LXVv, cap. 145, margen izquierdo superior.

\section{$[15] 41 / /[\mathrm{n}]$ atural $<\mathrm{G}>$}

Comentario. Las apostillas se refieren a la fecha del asesinato de F. Pizarro y a su condición de hijo natural. Las reúno aquí porque se encuentran muy próximas una de la otra y porque se refieren a dos datos inmediatamente sucesivos en el texto de Gómara. Ahora bien, la que tiene especial interés es la segunda, ya que corrige a Gómara, en la medida en que éste escribe "hijo bastardo" y no "hijo natural". Todo el pasaje en el que se encuentra esta caracterización fue citado por Garcilaso en HPerú, lib. III, cap. 9, y luego criticado y rectificado. Veámoslo:

Era hijo bastardo de Gonçalo Piçarro capitan de Nauarra, nacio en Trugillo y echaron lo ala puerta dela yglesia, mamo una puerca ciertos dias, no se hallando quien le quisiesse dar leche. Reconociolo despues el padre, y traya lo a guardar sus puercos, y assi no supo leer: dio les vn dia mosca alos puercos, y perdio los no oso tornar a casa de miedo, y fuese a Seuilla con vnos caminantes, y de allí alas Indias. Estuuo en Santo Domingo, passo a Uraua con Alonso de Hojeda, y con Vasco Nuñez de Valboa a descubrir la mar del sur, y con Pedrarias a Panama. Descubrio y conquisto lo que llaman el Peru...

El Inca censura acremente a Gómara en lo que sigue a la cita: 
Todas son palabras de aquel autor, sobre las cuales havía mucho que reprehender (si nos fuera lícito), assí al que las escrivio como al que se las dió en relación, porque no era razón dezir cosas tan baxas de un cavallero de quien él mismo ha escrito tantas grandezas tan hazañosas en armas, aunque fueran verdades, sino callarlas, cuanto más que no tienen verisimilitud alguna.

Luego procede a un minucioso cuestionamiento de lo señalado por Gómara en el pasaje citado. En cuanto a la rectificación que ya aparece en la apostilla, Garcilaso también emplea en su texto el adjetivo "natural", sin hacerse eco de la palabra "bastardo" usada por Gómara. Más bien, reivindica aquel adjetivo, poniéndolo en el contexto del reconocimiento que tuvo Francisco por parte de padre y madre: "...fue hijo natural de su padre y de su madre, reconocido por tal dende antes que nasciera". No hace falta subrayar la importancia de esta reivindicación desde el punto de vista de nuestro ilustre mestizo. En este caso Garcilaso se limitó a una rectificación léxico-conceptual en la apostilla a Gómara, sin adelantar lo que luego desarrolló en el texto de la HPerú y sin cuestionar explícitamente lo dicho por el soriano. Cf., en cambio, la apostilla 49, donde hay una recusación del que dio la relación al autor e, indirectamente, del autor mismo.

66) Fol. LXVv, cap. 146, margen izquierdo inferior.

[ent]ierro // [del] marques

Comentario. La apostilla aparece al margen de la porción de texto en el que se relata el acontecimiento señalado. Cf. al respecto HPerú, lib. III, caps. 6 y 7.

67) Fol. LXVIv, cap. 148, margen izquierdo inferior.

[Gar]cilasso de // la vega fue // [capitan] de caua//[1lo] en esta // [bat]alla/. // [Go]mez de Tor//[doy]a fue mae//[sse] $[\mathrm{d}]$ e campo $<P B: \mathrm{G}>$

Comentario. Las dos informaciones que contiene esta apostilla, y que están separadas por una línea trazada entre ellas, agre- 
gan precisiones al relato de Gómara sobre la llegada del gobernador Vaca de Castro al Perú y sobre los preparativos para la batalla contra Almagro el mozo. En el mismo capítulo Gómara había mencionado al padre del Inca entre los que reciben a Vaca de Castro en Trujillo; en cambio, no lo vuelve a mencionar entre los capitanes de caballo nombrados. Al terminar la mención de cuatro de éstos Gómara dice "y otros", palabras que han sido subrayadas para remitir al agregado. En HPerú, lib. III, cap. 13, Garcilaso precisa que los capitanes fueron seis, citando a Pedro Ansúrez y a su padre. También la función de su tío Gómez de Tordoya se precisa en este capítulo de HPerú.

68) Fol. LXVIIr, cap. 150, margen izquierdo inferior.

15 de septiembre // 1542

Comentario. En la apostilla se repite la fecha de la batalla de Chupas que menciona Gómara. Pero en HPerú, lib. III, cap. 17, Garcilaso sigue a Zárate al consignar como fecha el 16 de septiembre.

69) Fol. LXVIIv, cap. 150, margen izquierdo inferior.

[30]0 muertos

[40]0 heridos

Comentario. Repite los números dados por Gómara como saldo de la batalla de Chupas; en HPerú, lib. III, cap. 18, Garcilaso consigna las mismas cifras, mencionando como fuente al cronista soriano.

70) Fol. LXVIIIr, cap. 151, margen derecho central.

Salazar / / Bastidas // Morillo / tirado $<\mathrm{G}$ ? $><P B: \mathrm{S}>$

Comentario. Esta relación de nombres (hay uno anterior, del cual apenas quedan restos que quizás se pueden leer como "to", de Antón) aparece en el margen del lugar que el texto de Gómara dedica a la huida de Almagro y algunos de los suyos al 
Cuzco, luego de la derrota de Chupas. En el Cuzco, Almagro fue traicionado por sus propios secuaces. Dice Gómara: “...mas su teniente Rodrigo de Salazar de Toledo, y Anton Ruiz de Guevara Alcalde, y otros vezinos lo echaron preso...". La lista que da la apostilla parece hacer alusión a los responsables: no hay duda en el caso de Salazar, mencionado por Gómara. Los nombres de los restantes no aparecen tampoco en HPerú, lib. III, cap. 17, lugar en el que Garcilaso se refiere a este hecho, mencionando sólo entre los responsables de la prisión de Almagro a Salazar y a Ruiz de Guevara. Tampoco los menciona Zárate, en cuya Historia (y en la de Gómara) se basa el Inca para escribir su versión de Chupas. En cambio, los cuatro mencionados en esta apostilla, más un quinto, aparecen como responsables del asesinato de Pedro de Puelles, que se trata más adelante. Cf. apostilla 93.

71) Fol. LXVIIIr, cap. 151, margen derecho central.

Diego Me $n[\mathrm{dez}]$

Comentario. Ubicada inmediatamente debajo de la anterior, esta apostilla repite la alusión de Gómara a este personaje, al que llama Diego Méndez Orgoños (nombre que aparece subrayado en el ejemplar) y de quien dice que pudo escapar a las ejecuciones de Vaca de Castro: “...se solto, y se fue al Inga que estaua en los Andes, y alla le mataron despues los indios". Sobre este último punto Gómara trata más adelante ampliamente, y también Garcilaso, como se verá. Cf. apostilla 78. En $P B$ (p. 758) se atribuye erróneamente "Diego Méndez Orgoños" al anotador, y se dice que éste (Silvestre, según $P B$ ) habría tenido, por nombrarlo de este modo, una vinculación íntima con Méndez, hermano de Rodrigo Orgoños, lo cual denunciaría además una "subconsciente inclinación almagrista". También Zárate se refiere a Diego Méndez, llamándolo "hermano de Rodrigo Orgóñez", en pasaje citado por Garcilaso (HPerú, lib. III, cap. 13).

72) Fol. LXVIIIr, cap. 151, margen derecho inferior.

millon y [medio] 
Comentario. La apostilla repite la cifra que da Gómara respecto de los indios muertos hasta entonces en las guerras civiles. Garcilaso repite esta cifra en HPerú, lib. III, cap. 19, remitiéndose explícitamente a Gómara.

73) Fol. LXVIIIv, cap. 152, margen izquierdo superior.

[añ]adir // [15]42<G>

Comentario. Se trata del capítulo en el que Gómara se refiere a los antecedentes y a la redacción de la "Nuevas Leyes". El clérigo soriano menciona a los miembros designados por el rey para que entendiesen en el asunto, señalando títulos y condiciones. Garcilaso aborda el tema en HPerú, lib. III, cap. 20 y su versión se basa parcialmente en Gómara, a quien remite en dos ocasiones, una al respecto de uno de los miembros, García Manrique, y otra a propósito de la fecha (anotada en la segunda parte de la apostilla) y el lugar de las ordenanzas. La primera parte de la apostilla parece indicar la voluntad del Inca de agregar algo a una versión anterior sobre el asunto (¿la de HPerú?), pero no podemos saber exactamente qué. Lo cierto es que la apostilla aparece a la altura de la línea en la que Gómara dice: "Juntauan se a tratar y disputar con el cardenal, que posaua en casa de Pero Gonçalez de Leon". Pero este particular no pasa al texto de Garcilaso. Quizá la apostilla, por lo tanto, se refiera a otros detalles del texto de Gómara. Lo cierto es que éste no es la única fuente: por ejemplo, Garcilaso no menciona a todos los participantes, sino sólo a aquellos que, según su versión, opinaron en contra de la "Leyes Nuevas". Gómara sólo dice que el acuerdo tomado no fue unánime: "Y ordenaron, aunque no con voto de todos...".

74) Fol. LXVIIIv, cap. 154, margen inferior.

por ser odiosa la nota se borro $<\mathrm{G}>$

Comentario. Esta apostilla aparece debajo de otra que ha sido cuidadosamente tachada, de modo que resulta imposible leer su texto. Se refiere a una frase en que se da cuenta de la llegada al Perú del virrey Núñez Vela, a quien se caracteriza de este modo: 
“...cauallero principal, y veedor general de las guardas, hombre rezio de condicion que assi se requeria para essecutar las leyes al pie de la letra”. Es esta frase, que aparece subrayada en el ejemplar de Gómara, la que, obviamente, suscita el comentario "odioso" que dice Garcilaso (las últimas palabras del mismo parecen haber sido "por loco", con lo cual se echa de ver el calibre de la anotación). Sin embargo, el juicio de Garcilaso sobre la personalidad de Núñez Vela es más comprometido que el de Gómara (cf. el final del Comentario a la apostilla siguiente).

75) Fol. LXIXr, cap. 154, margen derecho superior.

veis co[mo?] / / < testado era la averiguacion?> // que haz[ia] // aun ante[s] [que?] // entre en [la] // gouerna[cion]

Comentario. La apostilla se refiere a las primeras medidas tomadas por el virrey Nuñez Vela al llegar a Nombre de Dios, medidas que suscitan el subrayado (que indico luego en la cita) del texto y el comentario adverso. Está mal conservada, pues se han perdido varias letras por refilado; además, la segunda línea está tachada y no se lee bien, de modo que la lectura propuesta es conjetural (se puede reconocer quizá "era" y "la" como primeras palabras de la porción tachada). Dice Gómara en el pasaje que suscita el comentario:

Partio pues Blasco Núñez con la audiencia, y llego al Nombre de Dios a diez de Enero de mil quinientos quarenta y quatro: hallo alli a Christobal de Barrientos y otros peruleros de partida para España con buena cantidad de oro y plata: y requirio a los alcaldes, embaraçassen aquel oro hasta que se aueriguasse de que lo lleuauan: ca le dixeron que aquellos hombres hauian ve $n$ dido indios y traydolos en minas, cosa de que mucho se alteraron y quexaron los vezinos y los dueños del oro...

El Inca en HPerú, lib. IV, cap. 1 (capítulo basado en Gómara), al tratar de la llegada del virrey a Nombre de Dios, omite esta anécdota del oro, aunque se explaya, con juicio crítico, sobre otras medidas de virrey tomadas en Panamá y relativas a los indios de servicio traídos del Perú, cuyo traslado a su lugar de origen ordenó. El juicio de Garcilaso sobre Núñez Vela es severo, pues habla de su "rigor, aspereza y mala condición" (y, además, de su "imprudencia", en el lib. III, cap. 19). 
76) Fol. LXIXv, cap. 156, margen izquierdo central.

$[\mathrm{m}]$ ote

Comentario. La apostilla resalta con una palabra clave (también presente en el texto de Gómara) la anécdota a propósito del viaje del virrey de Trujillo a Lima. En efecto, dice el clérigo soriano: "Blasco Nuñez partio de Trugillo apriessa. Llego al tambo que dizen dela barranca, donde no hallo que comer, mas hallo un mote que dezia, el que me viniere a quitar mi hazienda, mire por si, que podra ser que pierda la vida". En HPerú, lib. IV, cap. 4, el Inca retoma la anécdota, elaborándola con mayor amplitud y separándose de Gómara en algunos detalles, el más significativo de los cuales es el texto mismo del mote, el cual, según Garcilaso, rezaba: "A quien viniere a echarme de mi casa y hazienda, procurare yo de echarle del mundo”.

77) Fol. LXIXv, cap. 156, margen izquierdo inferior.

[Dieg]o Mendez // [y] [otro]s seys // [españ]oles

Comentario. Cf. 78.

78) Fol. LXIXv, cap. 156, margen izquierdo inferior.

[muerte?] de $\operatorname{Ma} n / / \operatorname{co}[\mathrm{Yn}] \mathrm{ca}<\mathrm{G}>$

Comentario. Esta apostilla y la anterior, separadas por apenas un breve espacio, pertenecen al mismo contexto temático. Se trata, en efecto, de los españoles almagristas que, luego de la derrota de Almagro el mozo, lograron huir y encontraron refugio con Manco Inca en las alturas. Llegado el virrey a Barranca, enviaron a Gómez Pérez como delegado para pedir "licencia y salvoconducto" para el Inca, Diego Méndez y otros seis españoles (a esto se refiere la apostilla 77) refugiados, licencia que fue aceptada por el virrey. Sin embargo, retornado Gómez Pérez, se enemistó por cuestiones de juego de bolas con Manco y lo mató (referencia de la apostilla 78), como respuesta a lo cual todos los españoles fueron muertos por los indígenas. Garcilaso en HPerú, lib. IV, cap. 7, se refiere a este episodio, amplián- 
dolo y matizándolo. Remite al capítulo de Gómara y señala que difiere de su versión en la manera como Gómez Pérez mató a Manco (a estocadas según Gómara, de un golpe en la cabeza con la bola, según Garcilaso), ya que él recibió información "de los Incas que se hallaron presentes a aquella nunca jamás oída locura, cuando con terníssimas lágrimas la contaron a mi madre los parientes que salieron con el Inca Sairi Túpac, hijo deste desdichado príncipe...”.

79) Fol. LXX, cap. 157, margen derecho inferior.

Electi[on] de // Gonzalo Piçarro

Comentario. La apostilla corresponde a la línea en la que Gómara dice, respecto de G. Pizarro: "Assi que lo elegieron por general procurador". El capítulo entero de Gómara está citado en HPerú, lib. IV, cap. 8; luego de la cita, el Inca añade precisiones sobre el asunto de la elección de Pizarro.

80) Fol. LXX, cap. 157, margen derecho inferior.

protes[tas?]

Comentario. La apostilla se relaciona con la siguiente frase del texto de Gómara, relativa a quienes, sin llegar a revocar los poderes, se arrepintieron del apoyo que habían dado a G. Pizarro: "Aunque en secreto protestaron muchos del poder que le hauian dado, entre los quales fueron Altamirano, Maldonado, Garcilasso de la Vega". Todo el capítulo al que se refieren esta apostilla y la anterior fue reproducido en HPerú, lib. IV, cap. 8.

81) Fol. LXXv, cap. 158, margen izquierdo central.

suspen [sion] [de] // las orde //[na]nças

Comentario. La apostilla alude al párrafo en el que Gómara relata cómo el virrey "Suspendio las ordenanças por dos años, y hasta que otra cosa el emperador mandasse". Dicho párrafo aparece citado en HPerú, lib. IV, cap. 14, con una ligera modifi- 
cación inicial, que le permite a Garcilaso anudar el texto del soriano a su discurso.

82) Fol. LXXIr, cap. 159, margen izquierdo superior.

cifra

Comentario. Se refiere al pasaje en el que se habla de la cartas en cifra del licenciado Benito de Carvajal a su hermano el factor Guillén Suárez, cartas interceptadas por el virrey y que preludian el asesinato del factor por mano de Núñez Vela. Dicho pasaje fue transcrito en HPerú, lib. IV, cap. 13. Para los detalles del episodio del asesinato, el Inca cita ampliamente a Zárate y luego al Palentino. Al final del capítulo, vuelve a Gómara y cita el párrafo, también final, de la versión del clérigo soriano, párrafo señalado por medio de la apostilla 84 (cf.).

83) Fol. LXXIr, cap. 159, margen izquierdo superior.

Salazar // los Esco//bedos y // los demas // que huyeron

Comentario. Pone de relieve los nombres de algunos de los personajes citados por Gómara que huyeron de Gonzalo Pizarro luego de la muerte del factor, entre ellos a los sobrinos de éste, apellidados Carvajal y Escobedo. Cf. HPerú, lib. IV, cap. 13, donde se menciona a estos últimos por medio de una cita de Zárate.

84) Fol. LXXIr, cap. 159, margen derecho central. muerte $[\mathrm{del}] / /$ fator

Comentario. Cf. 82.

85) Fol. LXXIIr, cap. 161, margen derecho inferior. tribu[laciones] // del virr[ey]

Comentario. La apostilla resume el último párrafo del capítulo sobre la prisión del virrey. Garcilaso en HPerú, lib. IV, cap. 16, cita 
el párrafo de Gómara para ilustrar, justamente como dice la apostilla, las "tribulaciones" del virrey preso: "Gómara, haviendo dicho, aunque confusamente, todo lo de atrás <expuesto a través de una extensa cita de Zárate, J.L.R $>$, añade lo que sigue, que, por ser de tanta lástima acerca del pobre Visorrey, puesto en tales tribulaciones, lo puse como aquel autor lo dize, capítulo ciento y sesenta y uno, que es lo que se sigue". En verdad, el inicio de la cita no es literal y corresponde más bien a un resumen de lo que expone Gómara en la porción inmediatamente anterior.

86) Fol. LXXIIIr, cap. 164, margen izquierdo inferior.

fueron $36 / /$ los que se // huyeron $<\mathrm{G}>$

Comentario. La apostilla se refiere a quienes dejaron el bando de Gonzalo Pizarro cuando éste se dirigía a Lima para "suplicar de las ordenanzas", aunque, en el fondo, con intenciones de rebeldía. Gómara cita cuatro nombres, como parte de un conjunto mayor. En HPerú, lib. IV, cap. 10, Garcilaso da una larga lista, la primera con los quince principales (incluido su padre), lista en la que coinciden, como señala el autor, Zárate y el Palentino; luego añade otra lista con diecisiete nombres más, agregando: "y otros, cuyos nombres se me han ido de la memoria, que todos llegavan a cuarenta, y yo conocí muchos de los nombrados”. Llama la atención la diferente cifra que da en la apostilla, cifra que, al no ser redonda, deja suponer un recuento minucioso. Quizá, para cubrir sus vacíos de memoria, prefirió redondear la cifra en el texto de HPerú. Es curioso también que no incluya uno de los nombres mencionados por Gómara, a saber, el de Rodrigo Núñez.

87) Fol. LXXIIIv, cap. 164, margen izquierdo superior.

saluo conducto

Comentario. Se corresponde con el pasaje de Gómara en el que se habla del salvoconducto solicitado por algunos del bando de Pizarro que se querían pasar al virrey: "El virrey se lo dio para todos, salvo para Piçarro, Francisco de Carvajal y otrros assi: de que mucho se enojaron Piçarro y su maestre de campo, y 
dieron garrote a Gaspar Rodriguez, Felipe Gutierrez y Arias Maldonado, que se carteauan con el virrey". Garcilaso trata ampliamente estos asuntos en HPerú, lib. IV, cap. 12, aunque sigue a Zárate "más que a otro porque se halló presente en ellos”. Sin embargo, al final del capítulo vuelve a Gómara y cita (pero con un final diferente, ya que elimina la referencia a Arias Maldonado y al hecho de cartearse con el virrey) el fragmento transcrito arriba.

88) Fol. LXXIVr, cap. 165, margen derecho central.

prouision [de] // gouernadores

Comentario. La apostilla destaca el lugar en el que Gómara habla del nombramiento de tenientes por parte de Pizarro ya gobernador. Cf. HPerú, lib. IV, cap. 19, sobre el mismo asunto con citas de Zárate.

89) Fol. LXXIVr, cap. 166, margen derecho inferior.

arrepent[imiento] [del] // visorey

Comentario. Corresponde al pasaje en el que Gómara relata cómo el oidor Juan Álvarez soltó al virrey en Huaura, con lo cual "Blasco Nuñez penso que lo tenia todo hecho en verse puesto en libertad: mas despues se arrepintio muchas vezes, diziendo que Juan Aluarez lo hauia destruido en soltalle". Cf. HPerú, lib. IV, cap. 15, basado en Zárate.

90) Fol. LXXVr, cap. 168, margen izquierdo inferior.

$[\mathrm{d}]$ os capitanes // [a]lancea//[d]os

Comentario. Corresponde al lugar en el que Gómara se refiere a la persecución del virrey por parte de Pizarro. En el curso de la huida Blasco Núñez entra en duda sobre la lealtad de su gente, alancea a dos capitanes y mata a estocadas a su maestre de campo. El pasaje es citado por Garcilaso en HPerú, lib. IV, cap. 26. 
91) Fol. LXXVIIr, cap. 170, margen derecho central.

700 legu[as]

Comentario. Se trata del capítulo "De lo que hizo Centeno en la villa dela Plata...". La apostilla es una rectificación de la distancia entre Quito y La Plata, que Gómara da como de "quinientas leguas" a propósito de la orden de G. Pizarro a Carvajal, quien se encontraba en Quito, de reducir a Centeno, quien se encontraba en La Plata. El episodio se halla en HPerú, lib. IV, cap. 36; antes, cap. 30, se consigna la distancia correcta entre ambas ciudades por medio de una cita de Zárate.

92) Fol. LXXVIIIr, cap. 171, margen derecho central.

Francisco Her[nandez] // de Cacere[s]

Comentario. Gómara menciona a este capitán del virrey en el contexto de la disposición del ejército para la batalla final con G. Pizarro, y la apostilla, acompañada del subrayado del nombre, lo pone de relieve. Se trata de Francisco Hernández Girón, protagonista luego de la última de las guerras civiles del Perú. Garcilaso lo menciona en el lib. IV, cap. 35 de HPerú, entre los prisioneros del bando del virrey, haciendo referencia a la denominación de origen que le da Gómara: “...quedaron heridos Don Alonso de Montemayor y el governador Sebastián de Belalcáçar y Francisco Hernández Girón, a quien Gómara llama Francisco Hernández de Cáceres...”. PB señala a Silvestre como responsable de poner de relieve los nombres de sus coterráneos cacereños; sin embargo, cabe sospechar que, en este caso, se trate de una apostilla destinada a identificar una mención requerida de enmienda.

93) Fol. LXXXIr, cap. 180, margen izquierdo inferior.

Pedro de // Puelles muerto / / Tirado / / Morillo / / Bastida / / Salazar $<\mathrm{G}>$

Comentario. El texto de Gómara se refiere a los que se alzaron contra Pizarro para plegarse a Gasca; entre ellos se menciona a 
"Rodrigo de Salazar en Quito, dando de puñaladas a Pedro de Puelles que pensaua declararse otro dia por el rey segun dixera a Diego de Urbina”. La apostilla menciona a Salazar y añade otros tres nombres, cuya participación en el asesinato queda clara por la versión del Inca, quien en HPerú, lib. V, cap. 8, trata circunstanciadamente del asesinato de Pedro de Puelles. En ese contexto menciona como cómplices de Salazar a los señalados en la apostilla y añade un cuarto, llamado Hermosilla. En la versión de Garcilaso se aclara, además, la responsabilidad de Diego de Urbina, mencionado de paso en el texto de Gómara. Hago notar, finalmente, que en esta apostilla hay una separación entre la mención de la muerte de Puelles y los otros nombres, pero se trata de un mismo contexto, y es claro que Garcilaso añade nombres que no están en el texto para tenerlos presentes a propósito de la muerte de Puelles.

94) Fol. LXXXIv, cap. 181, margen derecho central.

Diego

Comentario. La apostilla constituye una corrección del nombre de unos de los secuaces de Gonzalo Pizarro en la última etapa de su rebelión, el cual aparece en Gómara como Alonso Maldonado el rico. "Alonso" está tachado en el texto. El personaje aparece, con el nombre correcto, en diversas partes de HPerú.

95) Fol. LXXXIIr, cap. 182, margen izquierdo inferior.

$1212 / /$ centeno

Comentario. En realidad se trata de dos apostillas separadas pero que provienen de la misma mano y que sólo repiten pasajes del texto de Gómara, razón por la cual las hemos juntado. La primera repite en números arábigos la mención de la cantidad de hombres con que contaba Centeno para la batalla de Huarina con G. Pizarro. La segunda pone de relieve el nombre del caudillo, en el lugar en el que Gómara señala que no pudo tomar parte en la batalla por estar "con dolor de costado y sangrando". Con respecto a lo primero, en HPerú, lib. V, cap. 18, Garcilaso se refiere al número de hombres del ejército de Cen- 
teno y cita en primer lugar a Gómara sobre los 1212; luego consigna los datos divergentes de Zárate ("poco menos de mil") y del Palentino ("más de novecientos"), para agregar finalmente: "yo siempre oí dezir que eran mil y dozientos, los dozientos y sesenta de cavallo y ciento y cincuenta arcabuzeros y casi ochocientos piqueros". Sobre lo segundo, en el mismo capítulo, alude a la enfermedad de Centeno, aunque con menor detalle, pues dice únicamente: "Diego Centeno, por estar enfermo, no entró en el escuadrón ni se halló en la batalla; estava en unas andas, a la mira".

96) Fol. LXXXIIr, cap. 182, margen derecho inferior.

Antonio d [e] / / Vlloa

Comentario. Pone de relieve el nombre de uno de los capitanes de la caballería de Centeno, mencionado por Gómara como "Antonio de Ulloa de Caceres". También lo menciona Garcilaso en HPerú, lib. V, cap. 18 como "Antonio de Ulloa, natural de Cáceres, cavallero nobilíssimo” (cf. 92).

97) Fol. LXXXIIv, cap. 182, margen izquierdo superior.

[Migu?] el de // [Verga?] $\mathrm{ra}<\mathrm{S}>$ [...que] // [gome]z de $1[\mathrm{e}]$ on // [er]a de la par//[te] [de]l rey $<$ S $>$

[huye $] \mathrm{n}$ los de $[\mathrm{c}] \mathrm{e} n \mathrm{t}[\mathrm{en}] \mathrm{o}<\mathrm{S}>$

Comentario. Reúno estas tres apostillas de la misma mano que contienen -salvo la última que resume el final del capítulo en el que Gómara trata del desbande del ejército de Centeno en Huarina- un agregado y una corrección. El agregado se refiere, si es correcta la hipótesis de reconstrucción, a uno de los tres capitanes de Centeno (los otros fueron Francisco de Ulloa y Gonzalo Silvestre) que, según la versión de Garcilaso (HPerú, lib. V, cap. 19), durante la batalla de Huarina persiguieron a Gonzalo Pizarro y estuvieron a punto de matarlo. Ahora bien, en el texto de Gómara, la apostilla corresponde a la línea en la que se cuenta que Juan de Acosta, por parte de Pizarro, se adelantó - en un episodio de la batalla-con treinta arcabuceros, 
pero fue derribado y herido. Se puede sobrentender que quien lo derribó e hirió fue Vergara. En lo que respecta a la segunda apostilla, se trata de una corrección a Gómara, quien menciona al personaje como parte del ejército de Pizarro.

98) Fol. LXXXIIv, cap. 182, margen derecho superior.

Guadrami//ros. Guada//lupe. $<$ G $>$

Fue esta ba//talla a $21 / /$ de octubre de 1541

Esta men// tira me ha // quitado el // comer. quiça // por mejor. $<\mathrm{G}>$

Comentario. Reúno aquí tres apostillas que se encuentran al margen derecho del texto de Gómara sobre Huarina, a la altura de aquellas puestas en el margen izquierdo y ya comentadas. La primera y la tercera son de la misma mano, en este caso de Garcilaso. Sobre la segunda, en la que se agrega la fecha de la batalla, se puede dudar, pues la letra es diferente de la de las otras dos y parecida, en cambio, a las del margen izquierdo, que probablemente provienen de Silvestre. En cuanto a la primera, cabe decir que agrega los nombres de dos personajes no mencionados por Gómara, de los cuales trata Garcilaso en HPerú, lib. V, cap. 20: por consiguiente, la apostilla constituye una especie de ayuda-memoria para desarrollar la actuación de los mismos en Huarina. Ahora bien, parecería que este agregado contiene una corrección implícita a la apostilla del margen izquierdo sobre Miguel de Vergara, en el sentido de que se refiere al derribamiento y herida de Juan de Acosta, que habría sido responsabilidad de Guadramiros y de Guadalupe, y no del capitán Vergara. En efecto, Garcilaso dice:

...entonces salió a pelear con ellos Juan de Acosta. Un soldado de Diego Centeno, que se dezía fulano Guadramiros, que yo conoscí, alto de cuerpo y bien dispuesto, aunque hombre pacífico, que no presumía de la soldadesca, sino de la urbanidad, le dió un picazo en la gola, y, cevando la pica en ella, dió con él de espaldas tan gran golpe, que Juan de Acosta, al dar en el suelo, levantó ambas piernas en alto. A este tiempo llegó un negro, que también conoscí, que se dezía fulano Guadalupe, y le dió una cuchillada en ambas piernas por las pantorrillas, que, por ser el negro pequeño y ruinejo y la espada de negro tan ruin como su 
amo, no se las cortó ambas; pero todavía le hirió en ellas, aunque poco.

(Y sigue el texto con otros particulares sobre ambos personajes.) En lo que se refiere a la última de las apostillas transcritas, ella constituye un mentís al contenido de una frase de Gómara, que aparece subrayada en el texto, relativa al padre de Garcilaso: “...Piçarro corriera peligro, si Garcilasso no le diera un cavallo". Además, alude al fracaso de sus gestiones en la corte para obtener mercedes sobre los servicios de su padre. La reivindicación paterna y su versión de los acontecimientos se desarrollan ampliamente en un capítulo, el 23 del lib. V de la HPerú, titulado: "El autor da satisfacción de lo que ha dicho, y, en recompensa de que no le crean, se jata de lo que los historiadores dizen de su padre".

99) Fol. LXXXIIv, cap. 183, margen izquierdo inferior.

[g]arcila//sso dela // vega

Comentario. Repite el nombre del padre de Garcilaso (que aparece subrayado en el texto de Gómara), a quien se menciona como partidario de que Gonzalo Pizarro, luego de la batalla de Huarina, buscase un acuerdo con Gasca. El pasaje está citado literalmente en HPerú, lib. V, cap. 22.

100) Fol. LXXXIVv, cap. 186, margen izquierdo central.

Esto no lo // [dize] como pa//[sso] El acos//[ta] [r] espondio // [presum]iendo a[rre]// [met]amos y // [mur]amos co// [mo] [los] roma//[nos] dixo El // [piça]rro mas // [val]e mo$\operatorname{rir} / /[\mathrm{com}]$ o cristia/ $/$ nos $\langle\mathrm{G}$ ? $\rangle\langle P B: \mathrm{S}\rangle$

Comentario. Se trata, en el pasaje de Gómara al que corresponde esta apostilla, de la rendición de G. Pizarro a Gasca después de la derrota de Jaquijaguana. Según la versión de Gómara, Pizarro consulta a Juan de Acosta sobre lo que conviene hacer y éste le responde que se entreguen, a lo cual Pizarro "vamos dixo pues a morir como Christianos". La apostilla corrige la versión de Gómara sobre este episodio, desarrollado por Garci- 
laso en HPerú, lib. V, cap. 36, donde se inserta el diálogo con Acosta de modo muy cercano al de la apostilla; así, el texto de HPerú sirve para la reconstrucción de la misma, pues es evidente que Garcilaso la traspasa, sólo con algunas modificaciones menores, a su obra. Pero Garcilaso no rectifica explícitamente a Gómara a propósito del diálogo cuyo tenor corrige, e inmediatamente cita al soriano para comentar elogiosamente la decisión de Pizarro de entregarse. $P B$ reconstruye de otro modo la apostilla, aunque sin tener en cuenta HPerú.

101) Fol. LXXXIVv, cap. 186. Espacio entre capitulos.

mas necio es v.m. En dezir lo asi que El trist[e] // para Escaparse en la fuga mas nescesidad tenja de la azemila que de la carga y El que hu/ / ye no lleua ese Espacio /

todo lo que Este majadero // Escriue es con esta [con]//sideracion $<\mathrm{S}>$

Comentario. Se trata de una apostilla en dos partes, separadas por una barra y luego por una línea. Los rudos comentarios se refieren a la última línea del capítulo, en la que Gómara, a propósito del desbande del ejército de Pizarro, dice: "Uno de Piçarro topo una azemila cargada de oro, derribo la carga y fuesse con la bestia, no mirando el necio los lios".

102) Fol. LXXXIVv, cap. 187, margen inferior.

la restitucion delas esmeraldas. la vna de Altamirano $<P B: \mathrm{S}>$

Comentario. Esta apostilla agrega un particular relativo a Carvajal, de cuyo ajusticiamento se trata en este capítulo. El contenido de la apostilla se entiende a la luz de la lectura de HPerú, lib. V, cap. 40, titulado "Lo que hizo e dixo Francisco de Carvajal el día de su muerte, y de lo que los autores dizen de su condición y milicia”. En él cuenta Garcilaso que Carvajal, antes de ser ajusticiado, llamó al secretario de Gasca

...y con él habló muy despacio a solas, y al fin de la plática sacó tres esmeraldas finísimas que estavan horadadas como cuentas... Con ellas en la mano, tomando la mayor dellas aparte, dixo: "Se- 
ñor secretario, ésta es de los herederos de Antonio Altamirano; está apreciada en cinco mil pesos, que son seis mil ducados. Suplico a vuesa merced mande que se buelva a su dueño. Estotra es de fulano..."

Como se puede notar, la apostilla señala un tema no tratado por Gómara y que Garcilaso incluye en su versión de los acontecimientos referidos.

103) Fol. LXXXVr, cap. 187, margen izquierdo superior.

Es mentira / / y relacion / / de algu $n$ ene / / migo de Diego Cen// teno / <PB: G y $\mathrm{S}>$

Comentario. El mentís se refiere a la siguiente frase de Gómara (en la cual hay un subrayado que se indica): "Fue Centeno a ver le < a Carvajab la noche antes que lo matassen, y el hizo que no le conocia: y como le dixeron quien era, respondio, que como siempre lo hauia visto por las espaldas no le conocia, dando a entender que siempre le huyo". $P B$ cree que la primera línea es de Silvestre y el resto de Garcilaso. En efecto, hay algunas diferencias en la tinta y en el trazo. En cualquier caso, en HPerú, lib. V, caps. 39 y 40, Garcilaso se refiere a esta anécdota que circulaba en el Perú, y que fue recogida por el Palentino y por Gómara. Según Garcilaso, que objeta la veracidad de la misma, el Palentino la pudo tomar de Gómara. A continuación de esta indicación, el Inca, en el cap. 40, se refiere a otra anécdota a este respecto:

...es assi que un soldado de los más principales y famosos del Perú, que vino a España poco después que salió la historia de Gómara, topándose con él en Valladolid, entre otras palabras que hablaron sobre este caso le dixo que por qué havía escrito y hecho imprimir una mentira tan manifiesta no haviendo passado tal. Con éstas le dixo otras palabras que no se zufre ponerlas aquí. A las cuales respondió Gómara que no era suya la culpa, sino de los que davan las relaciones nacidas de sus passiones. El soldado le dixo que para esso era la discreción del historiador, para no tomar relación de los tales ni escrevir mucho sin mirar mucho, para no disfamar con sus escritos a los que merecen toda honra y loor. Con esto se apartó Gómara muy confuso y pesante de haver escrito lo que levantaron a Carvajal en dezir que no conocía a Diego Centeno. 
El tenor del discurso del soldado aludido es congruente con varias de las apostillas cuestionadoras de que nos ocupamos, de modo que nada impide que la referencia de Garcilaso sea justamente a Silvestre, quien había sido seguidor de Centeno en Huarina. La misma hipótesis se halla en $P B$.

104) Fol. LXXXVr, cap. 187, margen derecho superior.

Mas d[e] [cien?] // vi yo a[çotar] // y // fueron [los?] [primeros?] // Españo[les] // açota[dos?] [en?] [el?] // piru y [...] $/ /$ los $<$ Esp interlineado $>$ pe[rdieron?] // mucho [...] // y reput[acion?] // [...] ver // castigo [tan?] [in]//fame / // Garc[ilasso $]<\mathrm{G}><P B: \mathrm{S}>$

Comentario. Esta apostilla, referida a los castigos infligidos a los derrotados de Jaquijaguana, está muy mal conservada. Al final aparece la firma de Garcilaso, lo cual debería llevar a identificar la apostilla como del Inca, no obstante lo cual $P B$ la atribuye a Silvestre, quizá porque el trazo de la firma es algo diferente al de la apostilla misma y concuerda, más bien, con el de la parte que él atribuye al Inca. El contenido es similar al que Garcilaso expresa en un pasaje de HPerú, lib. VI, cap. 1. En efecto, allí, subrayando su condición de testigo presencial, como en la apostilla, dice lo siguiente:

Ahorcaron muchos soldados famosos de los de Piçarro, descuartiçaron otros muchos, y açotaron, en vezes de cuatro en cuatro y de seis en seis, más de cien soldados españoles. Yo los vi todos, que salíamos los muchachos de mi tiempo a ver aquel castigo, que se hazía con grandíssimo escándalo de los indios, de ver que con tanta infamia e vituperio tratassen los españoles a los de su misma nación, porque hasta entonces, aunque havía havido muchos ahorcados, no se havía visto español alguno açotado.

105) Fol. LXXXVr, cap. 187, margen derecho inferior.

por est[a] [con]//sulta de[zian] // En el pir[u] [que] // avian re[par]//tido la [tierra] // un villa[no] // un judi[o] [y] // vn mal $[$ christi $] / /$ ano $/ .<P B: S>$

Comentario. El capítulo de Gómara trata "Del repartimiento de haziendas e Indios que Gasca hizo entre los Españoles despues 
de la victoria". Dentro de él, aparece subrayada la siguiente frase, a la cual se refiere la apostilla: "Saliose pues a Apurima doze leguas del Cuzco, y alli consulto el repartimiento con el arçobispo delos Reyes Loayza, y con el secretario Pero Lopez...". En HPerú, lib. VI, cap. 1, Garcilaso alude al retiro de Gasca a Apurímac para tratar de los repartimientos con el arzobispo y el secretario, pero no añade la observación maledicente (una "bocanada de sátira popular" la llama Porras Barrenechea) de que da cuenta la apostilla. Sin embargo, en este mismo capítulo se refiere a los apodos injuriosos que daban a La Gasca y da cuenta de que, con motivo de conocerse el repartimiento, "muchos de los vezinos y soldados començaron a blasfemar y a dezir denuestos contra el Presidente, y públicamente dezían desvergüenças que assestavan a tiranía y nuevo alçamiento". Por lo demás, en el capítulo siguiente (HPerú, lib. VI, cap. 2), Garcilaso abunda sobre las desvergüenzas de los defraudados y cita todo el pasaje de Gómara que se inicia con la frase transcrita arriba y que termina con el fin del capítulo 187 del libro del soriano.

106) Fol. LXXXVIv, cap. 192, margen izquierdo central.

[cau?]sa de // [re]laciones // [fal]sas o ver//[da]deras

Comentario. La apostilla aparece al final del capítulo en el que Gómara enjuicia duramente la conducta de los peruleros y justifica las menciones (o ausencia de ellas) que hace en su libro, y asimismo se pone al reparo de las críticas aludiendo a las relaciones que utiliza: "Quien se sintiere calle pues esta libre y rico, no hurgue por su mal: si bien hizo y no es loado, eche la culpa a sus compañeros: y si mal hizo y es mentado, echela a si mesmo". En HPerú, lib. II, cap. 16, para narrar la muerte de Pedro de Alvarado en la batalla de Ezatlán (México), Garcilaso se basa en Gómara (cap. 210) y lo cita por extenso; sin embargo, interrumpe su utilización literal de este capítulo cuando el autor comienza a expresar su juicio negativo sobre la persona de Alvarado. El Inca contradice tal juicio, señalando que Gómara fue víctima de la relación de algún envidioso. Luego de lo cual agrega la siguiente reflexión, que incluye una cita final de Gómara (levemente modificada, como se verá, a fin de que la frase se independice sintácticamente de su contexto), la cual corresponde justamente a la apostilla que comentamos y la aclara: 
De lo cual < de haber tomado alguna relación falsa como base de su texto> quiso el mismo autor desculparse, entendiendo que havían de ser falsas algunas de las relaciones que le davan, y assí, en el capítulo ciento y noventa y dos, hablando en el propósito de las relaciones, dize: "Quien bien hizo y no es loado, eche la culpa a sus compañeros”, etc. Dízelo porque sabía que en todos estados hay muchos compañeros embidiosos y maldizientes, indignos de la compañia de los buenos, que, en lugar de dezir verdad, dizen mentira.

107) Fol. LXXXVIv, cap. 193, margen derecho inferior.

3 millones // 600M pesos

Comentario. El capítulo al que se refiere la apostilla trata de la partida de Gasca del Perú y del robo, en Panamá por parte de los Contreras, de los dineros que había embarcado en Lima. Dice Gómara en frase parcialmente subrayada por el apostillador: "Embarco millon y medio para el rey, y otro tanto y mas de particulares". La primera parte de la apostilla consigna la suma de los montos parciales; la segunda parte alude a la cantidad, también mencionada por Gómara en el mismo contexto, dejada en Panamá por no tener en qué llevarla a Nombre de Dios (M está por el signo de mil). En su versión de este episodio Garcilaso menciona las mismas cifras, remitiéndose a Gómara como fuente (HPerú, lib. VI, cap. 11).

108) Fol. LXXXVIIr, cap. 194, margen derecho central.

es me $n$ t[ira] // de much[as] // colores

Comentario. La apostilla aparece en el capítulo "De la calidad y temple del Peru con algo de las costumbres" y se refiere a la indicación de Gómara de que en el Perú "Siembran algodon que de suyo es azul, verde, amarillo, leonado y de otras colores".

109) Fol. LXXXVIIr, cap. 194, margen derecho inferior.

miente [qui] //en se lo $\mathrm{d}[\mathrm{ixo}]<P B: \mathrm{S}>$ 
Comentario. El mentís se refiere a la frase (que subraya el anotador, como se indica) en la cual Gómara afirma que los indígenas de la zona de los Andes "son por la mayor parte tuertos, o ciegos, que por marauilla se hallan dos personas juntas, que la vna no sea tuerta". $P B$ lee "miente en se lo dezir", lo cual no sólo es anómalo lingüísticamente sino que no toma en cuenta las letras que faltan por el refilado antes de "en".

110) Fol. LXXXVIIv, cap. 194, margen izquierdo superior.

[no] [ha]y lobos $/<\mathrm{G}>$

[no] [1] es tuuuie $/ /$ [ron] los Yndios $<\mathrm{G}$ ? $>$

Comentario. Cuando Gómara señala los animales que había en el Perú, el anotador subraya "lobos", para desmentir luego tal afirmación en la apostilla. En $C R$, lib. VIII, cap. 18, que trata de los animales del Perú, Garcilaso no menciona los lobos; más bien, en el libro IX, cap. 21, declara explíctamente que no los había. La segunda de las apostillas que he reunido bajo este número parece provenir de otra mano y se refiere a la parte del texto en la que se mencionan los productos que confeccionaban los indios con lana: entre ellos se encuentran los colchones (voz que aparece subrayada), objeto de la rectificación. Cf. $C R$, lib. VI, cap. 1:

No supieron o no quisieron la invención de los colchones, y puédese afirmar que no la quisieron, pues, con haverlos visto en las camas de los españoles, nunca los han querido admitir en las suyas, por parecerles demasiado regalo y curiosidad para la vida natural que ellos professavan.

111) Fol. LXXXVIIv, cap. 195, margen izquierdo inferior e inferior. Fol. LXXXVIIIr inferior.

[si] [1] os vuo de [los] gozques ah [un?] [de los chicos y grandes?] $<$ las dos primeras palabras se leen difíilmente debajo del pegado de la rotura del margen; lo que sigue es del todo conjetural, pero basado en el texto de CR; cf. infra) $>$ de los de [cace] ria como gal[gos] lebre[les] perdigue[ros] podencos $[\mathrm{ma}]$ stines ala[nos] nj de los [ma]s pequeños [de] [f]alda que [las] damas ti[enen] En tanto [no] los auia 
[verdad] era prue[ua] desto Es [que] de todo a[qu] ello que no [au]ia en la tierra antes que los Españoles Entraran En ella no tenjan nombre En su lengua con que nombrar[lo] nj lo auian menester y asi oy llaman al cauallo cauallo y a la vaca vaca y a la cabra cabra y por consiguiente a todas las cosas que de España se han lleuado que ellos no tenjan/y al perro llaman [al]lco <hay resto de la primera $l>$ que Es nombre proprio En la lengua del cuzco para dezir perro. y asi mjsmo vuo ratones que En la mjsma [1] engua llaman vcucha y por que ay dos diferençias dellos como aca ratas y ratones para diferen[ciar]los alas ratas llaman s[un]dur < por rotura se ve sólo la parte superior de la segunda y tercera letra; en cambio la " $d$ " se lee bien $>$ vcucha y a los ratones sola mente vcucha / que como su reu[erencia] <raya transversal hacia el margen inferior del folio siguiente para indicar que sigue la anotación $>$ Escriue por relaciones dize mill disparates por que los que se las dauan por hacerse muy platicos con el deuuian de dezirle quanto se les venja a la boca y asi Escriuio mentiras En perjuizio de caualleros y personas muy principales que merecia que quemaran El libro y a quien hizo <esta palabra está escrita sobre un "lo" anterior que ha sido enmendado para hacerlo compatible con la corrección siguiente, cf.> la relacion <estas dos últimas palabras están escritas en la entrelínea encima de una palabra tachada: debajo de la tachadura se lee "escriuio"> dexo aparte El loor que dize de muchos que no merecen mas que los otros la ynfamja pero Esto Es menos culpable.

Comentario. El capítulo de Gómara en el que se encuentra esta apostilla y otras dos más se titula "De la cosas notables que hay y no hay en el Peru". En el siguiente pasaje se hallan subrayadas las porciones que indicamos, las cuales motivan la presente apostilla (que ocupa casi tres márgenes) y la siguiente (111):

No hauía cauallos ni bueyes, ni mulos asnos, cabras, ouejas, perros: a cuya causa no hay rauia alli, ni en todas las Indias. Tampoco hauia ratones, hasta en tiempo de Blasco Nuñez, remanecieron tantos de improuiso en san Miguel y otras tierras, que royeron todos los arboles, cañas de azucar, mayzales, hortaliza y ropa sin remedio alguno, y no dexaua $n$ dormir los Españoles, y espantauan los Indios.

La parte de la apostilla que se encuentra en el folio LXXXVIIr está muy deteriorada, pues el refilado del libro ha suprimido varias letras. Es posible hacer la reconstrucción con la ayuda de diversos capítulos de $C R$, ya que Garcilaso transvasa parte (no todo) el contenido de esta apostilla a su obra. Así, en los que se refiere a los perros, y en desmentido parcial de lo que dice Gó- 
mara, Garcilaso afirma en el lib. VIII, cap. 16, que existían gozques: "De lo perros que los indios tenían, dezimos que no tuvieron las diferencias de perros castizos que hay en Europa; solamente tuvieron de los que acá llaman gozques; havíanlos grandes y chicos: en común le llaman alco, que quiere dezir perro". En cuanto a los otros, en el lib. IX, cap. 16, habla de los que no había: "ni aun perros castizos para sus cacerías, como galgos, podencos, perdigueros, perros de agua ni de muestra, ni sabuesos de traílla o monteros, ni lebreles ni aun mastines para guardar sus ganados, ni gozquillos de los muy bonicos que llaman perrillos de falda"; y a continuación insiste en que existían los gozques: "de los perros que en España llaman gozques havía muchos, grandes y chicos". En el siguiente capítulo, el 17 del mismo libro, se refiere a los lebreles, alanos y mastines como perros importados a América, y en el cap. 21 reafirma, con referencia a Perú: "Perros castizos, de los que atrás quedan nombrados, no los havía en el Perú; los españoles los han llevado". Ahora bien, respecto de la "prueba" lingüística que se aduce en la apostilla, Garcilaso expresa una opinión contraria a ella en $C R$, lib. IX, cap. 20, aunque con referencia a los gatos, negando que baste la presencia del nombre para inferir la existencia del objeto:

Digo esto porque no entienda el español que por darles los indios nombre diferente de gato <micitu, de ;miz, miz!, oído a los espanoles $>$, los tenían antes, como han querido imaginar de las gallinas, que porque los indios les llaman atahuallpa, piensan que las havía antes de la conquista, como lo dize un historiador < se trata del P. Acosta, lib. IV, cap. 35>, haziendo argumento que los indios tuvieron puestos nombres en su lenguaje a todas las cosas que tenían antes de los españoles, y que a la gallina llaman gualpa; luego, havíalas antes que los españoles passaran al Perú. (cf. también $C R$, lib. IX, cap. 23).

Como se puede percibir, todo esto va en contra de lo que se dice en la apostilla, "haciendo argumento" de los nombres alco y ucucha. En cuanto a este último y a sus referentes, Garcilaso tiene una opinión parcialmente distinta de aquella expresada en la apostilla, en el sentido de que si bien afirma la existencia de los ratones antes de la llegada de los españoles y consigna el nombre ucucha (todo ello contradiciendo explícitamente a Gómara), rechaza, disociándose de la apostilla, que existieran 
las ratas (lib. IX, cap. 22). No hay rastros de la expresión sundur ucucha, de la que "se hace argumento" en la apostilla ${ }^{27}$. Lo que podríamos considerar la segunda parte de la apostilla, aquella que contiene una evaluación general de la obra de Gómara, se asemeja a otras atribuidas a Silvestre, caracterizadas por la agresividad de la expresión (como se ha visto, hay un pasaje corregido, cuyo tenor anterior era aún más virulento). Curiosamente, justo cuando Garcilaso comienza a hablar de las ratas y se refiere a la opinión de Gómara de que no había ratones en el Perú antes de los españoles, dice del soriano, al iniciar el cap. 22 del lib. IX:

Resta dezir de las ratas, que también passaron con los españoles, que antes de ellos no las havía. Francisco López de Gómara, en su Historia general de las Indias, entre otras cosas (que escrivió con falta o sobra de relación verdadera que le dieron) dize que no havía ratones en el Perú hasta en tiempo de Blasco Núñez Vela. Si dixera ratas (y quiçá lo quiso dezir), de las muy grandes que hay en España, havía dicho bien, que no las huvo en el Perú.

27 Suntur es palabra registrada ya en 1586 por el anónimo autor del Vocabulario y phrasis en la lengua general de los indios del Perú llamada quechua (Imprenta Rímac, Lima, 1951) y luego por D. GonzÁlez Holguín, Vocabvlario de la lengua general de todo el Perv llamada qquichua o del Inca (Imprenta Santa María, Lima, 1952 [1608]). Ambos consignan el sustantivo suntu "montón" y el verbo suntu- "amontonar"; atestiguan, asimismo, el compuesto suntur huaci con el significado "casa hecha a manera de pirámide" (el primero) y "casa redonda" (el segundo). También L. Bertonio (Vocabvlario de la lengua aymara, ed. facs., La Paz, 1984 [1612]) registra para el aimara un verbo sun$t u$ - "amontonar, juntar piedra, barro, leña y otras cosas como estas", además del compuesto sunturuuta "casa que tiene el techo cuadrado sin moxinete". A juzgar por estos datos (reunidos gracias a la ayuda de R. Cerrón-Palomino), la raíz parece estar asociada a la noción de volumen (formar volumen, tener volumen), más que a una determinada forma, lo cual explica que, aplicado a construcciones, el adjetivo suntur pudiese referir tanto a lo "redondo", como a lo "piramidal" (además de lo "cuadrado", en aimara). El propio Garcilaso atestigua el término suntur con el alcance que señalamos, pues en HPerú, lib. I, cap. 32, habla de un aposento que había pertenecido a Huayna Cápac, y en el que fueron alojados Hernando de Soto y Pedro del Barco durante su primera estancia en el Cuzco, y dice que se llamaba Sunturhuaci, "que es casa o pieça aventajada". Como se ve, se explica fácilmente la utilización de suntur a propósito de las ratas, vistas como ratones grandes o voluminosos. El valor de suntur como "grande" está documentado también por E. Middendorf (cf. el vocabulario de A. Rosenblat, al final de su edición de HPerú, s.v. Sunturhuaci). 
Como se ve, hay en este punto una crítica que parece un eco atenuado de la contestación radical que se formula en la apostilla. Lo cierto es que, fuera esta apostilla de Garcilaso, de Silvestre o de otra mano, Garcilaso la aprovecha selectivamente, aunque siguiéndola de cerca, para su tratamiento de los respectivos temas en diversas partes de los Comentarios. Como en otros casos de apostillas largas y deturpadas, renunciamos a indicar por medio de dos barras el cambio de línea, a fin de no complicar en demasía la transcripción.

112) Fol. LXXXVIIv, cap. 195, margen derecho inferior.

Esto de los // ratones fue // una pestile $n / /$ cia que vino // que hizo gran//disimo Es//trago En la // tierra prin//cipalmente $/ /$ En la costa $<$ S? $><P B: \mathrm{S}>$

Comentario. Se refiere a la parte subrayada del texto de Gómara citado a propósito de la apostilla anterior. En $C R$, lib. IX, cap. 22, Garcilaso habla de las plagas de ratas y ratones en la costa del Perú. Al final del capítulo señala lo siguiente:

Por la costa del Perú, en diversas partes y en diversos años, hasta el año de mil y quinientos y setenta y dos, por tres vezes huvo grandes plagas causadas por las ratas y ratones, que, criándose innumerables dellos, corrían mucha tierra y destruían los campos, assí las sementeras como las heredades, con todos los árboles frutales, que desde el suelo hasta los pimpollos les roían las cortezas; de manera que los árboles se secaron, que fue menester plantarlos de nuevo, y las gentes temieron desamparar sus pueblos; y sucediera el hecho según la plaga se encendía, sino que Dios, por su misericordia, la apagava cuando más encendida andava la peste. Daños increíbles hizieron, que dexamos de contar en particular por huir de la prolixidad.

Como se ve, el autor se basa en el pasaje de Gómara y extiende la ampliación ya iniciada por la apostilla (la cual no aparece transcrita en Fac.).

113) Fol. LXXXVIIv, cap. 195, margen derecho inferior.

la fortaleza // del cuzco fue // el mas sober//uio edificio // que se a hallado // En todas las Yndias $<P B: \mathrm{S}>$ 
Comentario. La apostilla se hace eco de la mención de Gómara al final del folio: "Tal edificio era la fortaleza del Cuzco, fuerte, hermosa y magnifica...”. No aparece transcrita en Fac. A la fortaleza de Sacsahuamán están dedicados los caps. 27, 28 y 29 del lib. VII de $C R$.

114) Fol. LXXXVIII, cap. 196, margen izquierdo inferior.

toda esta rela//[cion] esta con//[fusa] [s]in dis//tincio $n$ de tiemp//os ni pro//uincias y // nasciones. Todas // estas malas // costumbres auia antes // de los Reyes //Yncas en di//uersas nas / / ciones y ellos / / las quitaron / / todas $<\mathrm{G}>$

Comentario. Esta apostilla alude globalmente (obsérvese "toda esta relación") al capítulo titulado "Del remate de las cosas del Peru", pero particularmente a aquellas referencias a las costumbres indígenas y a la personalidad de los indios, que Gómara presenta bajo una luz muy negativa. Varias porciones del texto están subrayadas, como se verá, y toda una línea aparece, sin más comentario, tachada, a saber aquella que contiene una lista de cualidades negativas: son "mentirosos, ladrones, crueles, someticos, ingratos, sin honra, sin verguença, sin caridad, ni virtud”. Cf. a este propósito lo que dice Garcilaso en $C R$, lib. II, cap. 8, motivado por la información de Cieza (a quien llama en este pasaje "un historiador") a propósito de los sacrificios humanos y de la antropofagia: “...de donde consta claro que por no dividir los tiempos y los lugares atribuyen muchas vezes a los Incas muchas cosas de las que ellos prohibieron a los que sujetaron a su Imperio, que las usavan en aquella primera edad, antes de los Reyes Incas" (cf. 37).

115) Fol. LXXXVIII, cap. 196, margen izquierdo inferior.

[...] En // ninguna parte // se guardo // con mas fi //delidad $<P B: \mathrm{S}>$

Comentario. La apostilla se refiere a la afirmación de Gómara de que las indias eran infieles: "ni ellas $<$ guardaban $>$ lealtad en matrimonio", afirmación que aparece subrayada. El comienzo de la apostilla no se lee porque la tinta está corrida. Podría decir "enteramente falso", como propone $P B$. 
116) Fol. LXXXVIIIr, cap. 196, margen derecho inferior.

El dado $[\ldots] / /$ den de [mas de (?)] // cinco punt[os] // sus quatro $[\mathrm{co}] / / \operatorname{mo} \operatorname{los} 8[\ldots] / /$ y En luga $[\mathrm{r}][\mathrm{de}] / /$ seis que $[\ldots]$ // ponen $\mathrm{v}[\ldots] / /$ [c] ada diez [con] // este dado [jue]gan mu[chas] // manera[s] [y] // diferencia[s] [de] // juegos $\langle P B: S>$

Comentario. La apostilla sobre los dados y los juegos de dados de los indígenas se deriva de una afirmación de Gómara, parte de la cual aparece subrayada, a cuyo tenor "Juega $n$ con vn solo dado de cinco puntos". Está muy mal conservada por el refilado que ha destruido varias letras y no se puede interpretar en todos los extremos sobre los que informa. Sin embargo, uno de los que se puede rescatar de la apostilla, a saber, la importancia del diez, viene confirmado por un pasaje de $C R$, lib. II, cap. 14, en el cual -luego de tratar de los decuriones incaicos, llamados chunca camayu - Garcilaso explica lo siguiente:

...y el mismo nombre chunca camayu, en otra significación, quiere dezir perpetuo tahur, el que trae los naipes en la capilla de la capa, como dize el refrán, porque llaman chunca a cualquier juego, porque todos se cuentan por números; y porque todos los números van a parar al dezeno, tomaron el número diez por el juego, y para dezir juguemos dizen chuncásum, que en rigor de propria significación podría dezir contemos por diezes o por números, que es jugar.

117) Fol. LXXXVIII, cap. 196, margen derecho inferior.

Miente [en] [to]//do esto [que] [ha] // dicho y p[lega?] // a dios que lo[s] [espa]//ñoles $\mathrm{p}$ [rediquen?] // la fe y a[prendan?] // [de?] [sus?] virtud[es] $<$ S? $>$

Comentario. Esta es una apostilla conclusiva de todo lo que se ha objetado a Gómara en los dos capítulos (195 y 196) densamente anotados. Está muy mal conservada por lo que se ha dicho respecto de la apostilla anterior, de modo que varias partes reconstruidas tienen un carácter fuertemente hipotético. Sin embargo, no parece caber duda de que se trata de una defensa final de los indios y de una invocación a los españoles. Es de notar que esta apostilla está separada en dos partes por el texto 
de la apostilla 111 que ocupa casi todo el margen inferior del folio. El anotador ha trazado, a la derecha de la 111, una línea semicircular que la delimita e indica que la (semi)línea que aparece debajo del texto de la 111 no pertenece a esta anotación sino a la 117.

118) Fol. XCIIIv, cap. 210, margen izquierdo central.

$1535 / /[\mathrm{h}]$ a de dezir // 1532

Comentario. La apostilla corrige la fecha 1535 dada en el texto de Gómara para el inicio de la expedición de Alvarado al Perú. En HPerú, lib. II, cap. 2, al tratar del asunto, y luego de citar a Gómara, como lo hemos indicado a propósito de la apostilla 48, agrega que, según otras versiones, los hombres de Alvarado fueron 800 y no 500; y a continuación dice, respecto de la fecha (1535): "Otro historiador antepone tres años de tiempo". Cf. también la cita en el Comentario siguiente.

119) Fol. XCIVr, cap. 210, margen entre capítulos.

y un hijo que se llamo Don Diego de Aluarado que mataron los Yndios despues / / de la Batalla de Chuqui inca que fue la del mariscal Alvarado y francisco Hernandez Giro [n] $<\mathrm{G}>$

Comentario. Se trata de un añadido a la información de Gómara, según la cual Alvarado sólo dejó una hija nacida de una india. En HPerú, lib. II, cap. 16 dice Garcilaso:

Sin la hija conocí un hijo suyo, mestizo, que se dezía Don Diego de Alvarado, hijo digno de tal padre. Assemejóle en todas sus virtudes, hasta en la desgracia del morir, porque a él y a otros muchos españoles muy nobles, que havían escapado de la batalla de Chelqui < sic > Inca, los mataron indios por los caminos, como lo diremos en su lugar, si llegamos allá.

Justamente en el lib. VII, cap. 18, se repite la información sobre Diego de Alvarado. 
120) Fol. final al verso del colofón.

Esta historia de mexico Es fama que la Escriuio el mjsmo fernando cortes como / / hizo julio cesar sus comentarios y que la dio a un secretario suyo para que la saca//se a luz por suya El qual se la presento a este gomara porque supo que se hazia // coronjsta de las yndias y mundo nuevo. La mjsma obra muestra como se fue // Escriuiendo por dias como yua suscediendo que por relacion agena no se podia Es//criuir tan largo nj tan declarado/. <G? $>$

Comentario. La apostilla se refiere a una segunda parte, dedicada a la conquista de México, que no se ha conservado en el ejemplar, pero que fue leída por el Inca, quien remite a ella. En $C R$, lib. II, cap. 8, Garcilaso se hace eco de su contenido, aunque sin mencionar explícitamente a Gómara:

...como lo cuenta <que había sacrificios humanos y antropofagia en México $>$ la historia de su conquista, la cual es fama cierta aunque secreta, que la escrivió el mismo que la conquistó y ganó dos vezes, lo cual yo creo para mí, porque en mi tierra y en España lo he oído a cavalleros fidedignos que lo han hablado con mucha certificación. Y la misma obra lo muestra a quien la mira con atención, y fué lástima que no se publicasse en su nombre para que la obra tuviera más autoridad y el autor imitara en todo al gran Julio César.

\section{OTRAS APOSTILLAS Y MARCAS DE LECTURA}

Ya se ha visto que hay varias apostillas que consisten en la repetición de una cifra o de un nombre presentes en el texto de Gómara. No todas ellas aparecen editadas y comentadas en la secuencia anterior, que sólo contiene las que me han parecido más relevantes en relación con la obra del Inca. Pero las restantes, aunque tengan una importancia menor, revelan, de todos modos, el interés de los anotadores del libro por un determinado lugar, por un determinado acontecimiento, por un determinado tema, por un determinado personaje ${ }^{28}$. Lo mismo

28 Por ejemplo, Cipango (cap. 14: apostilla muy mal conservada); la fecha de la capitulación de Santa Fe (cap. 15); los 3300 castellanos que pesaba un grano de oro llevado por Francisco de Bobadilla a la reina Isabel (cap. 32); Pinzón y Niño (cap. 75); Americo < Vespucci> (cap. 88); fechas 
vale para otras marcas de lectura que se encuentran a lo largo del ejemplar, en primer lugar los abundantes subrayados, muchos de los cuales están ligados a una determinada apostilla (como se ha visto por la edición y los comentarios anteriores). Pero también los subrayados no ligados a apostillas, $\mathrm{u}$ otras marcas, inclusive la indicación de "nota" al margen, tienen relevancia porque revelan puntos - en ocasiones curiosidades o anécdotas-que han suscitado la atención de los usuarios del ejemplar. Todo esto podría ser materia de consideración particularizada, que omitimos aquí para no extendernos en demasía y para evitar más prolijidad.

Es obvio que los subrayados y marcas no pueden ser atribuidos a determinada mano, lo cual no quita que se tienda a ver la del Inca historiador, por ejemplo, en la que subraya las referencias eruditas que hace Gómara en uno de sus capítulos iniciales (3) de carácter cosmográfico, o en la que pone de relieve la declaración del soriano de que se propone imitar a Polibio y Salustio al tratar separadamente las hazañas de Cortés en la conquista de México (cap. 50). Igualmente, se estaría tentado de atribuir al Inca - quien no escondió su ferviente devoción mariana ${ }^{29}$ - la marca consistente en tres breves rayas oblicuas al margen de la mención de apariciones de la Virgen durante la conquista y colonización de Cuba (cap. 51); o la que pone de relieve con dos breves líneas marginales la existencia de muchas cruces de palo y latón en los adoratorios yucatecos de Acuzamil y Xicalanco (cap. 55) - ya mencionadas un poco antes (cap. 52, cf. apostilla 12)-, visto el interés del Inca por el tema; o, finalmente, la que aparece al margen del texto del mensaje en verso enviado a Panamá dentro de un ovillo de algodón desde la isla del Gallo por un soldado descontento

del descubrimiento del Amazonas (cap. 86) por Pinzón (1500) y por Orellana (1543), las cuales se mencionan, con referencia explícita a Gómara, en $C R$, lib. VIII, cap. 22; fechas de las expediciones a La Florida o a otras regiones próximas (cap. 45, etc.); número (80) de soldados que llegaron con Almagro para reforzar la hueste de Pizarro en el primer viaje descubridor (número que aparece consignado en HPerú, lib. I, cap. 8). Etcétera.

29 Cf. la dedicatoria a la Virgen en la Historia general del Perú. Recuérdese, asimismo, la aparición de la virgen en socorro de los españoles durante el asedio del Cuzco por parte de Manco Inca y sus huestes (HPerú, lib. II, cap. 25) o el milagro cumplido en Pedro Maldonado, a quien el libro de horas de la Virgen que llevaba en el pecho salvó de morir atravesado por un arcabuzazo (HPerú, lib. V, caps. 9 y 10). 
(cap. 109), texto que Garcilaso cita en HPerú (lib. I, cap. 8), diciendo haberlo oído mucho en su juventud cuzqueña y haberse alegrado de encontrarlo luego en la Historia de Gómara.

Sobre otros subrayados o relieves de nombres de personas, muy abundantes, es más difícil pronunciarse. Pero, en cualquier caso, las apostillas -las editadas más arriba y las aludidas en este apartado-, los subrayados, las diversas marcas de lectura, son expresiones, por un parte, del compromiso emocional e intelectual con la materia de la obra del soriano y, por otra, de la voluntad -explícita en varias de las apostillas-de usar esta obra como base de un nuevo, en parte coincidente y en parte discrepante, discurso historiográfico.

\section{Consideraciones finAleS}

Llegados al final, permítaseme unas cuantas consideraciones (no conclusiones, pues numerosos asuntos quedan aún abiertos) que resuman algunos de los puntos que se han tratado de modo particularizado a propósito de cada caso.

En su gran mayoría, las apostillas a la Historia de Gómara dejan un eco en la obra del Inca, preponderantemente, como no podía ser de otro modo, en la de temática peruana ${ }^{30}$. Este eco, a veces, es directo, ya fuerte, ya leve y atenuado; otras, en cambio, más bien indirecto, en la medida en que las apostillas señalan - por medio de un nombre propio, de una palabra clave o frase resumidoras del contexto- un lugar importante del texto del soriano que luego aparece citado en los Comentarios o en la Historia general del Perú.

Si no en todos los casos, en un número alto, las abundantes citas de Gómara ${ }^{31}$ están anunciadas por una apostilla (por

${ }^{30}$ Con La Florida se relacionan, no obstante, algunas de las apostillas (9, $10,14)$; su número es exiguo, lo que se explica por el poco espacio que dedica Gómara al descubrimiento y conquista de esta zona, en general, y a la expedición de Hernando de Soto, en particular.

31 Más abundantes en HPerú que en $C R$. A este propósito cabe señalar que las numerosas y extensas citas de Gómara, en la primera de las obras mencionadas, que no están en correlación con una apostilla u otra marca de lectura, muestran a un usuario asiduo y buen conocedor del libro, al cual, después de apostillado, debía de volver constantemente, al ritmo de la redacción de la Historia del Perú, a fin de identificar otros pasajes que merecían ser citados textualmente o aludidos. 
ejemplo 2, 8, 11, 18, 26, 32, 33, 36, 41, 46, 48, 58, 61, 79, 80, 81, $82,84,85,90,95,99,105,107)$. Pero aparte éstas, señaladoras de un pasaje o de un capítulo de dicho autor, hay otras que consisten en indicaciones, luego añadidas a propósito de citas o de refundiciones del texto de Gómara (por ejemplo 14, 17, $56,57,69,112$, 119; pero no se aprovecha, por ejemplo, 1). Tales agregados se configuran, en ocasiones, más bien como rectificaciones o retoques a la versión de un episodio o de una anécdota narrada por el clérigo soriano (23, 28, 31, 47, 78, 97, $98,100)$, o se presentan incluso como anécdota nueva (15, 102). Pero no se agotan aquí las rectificaciones. Las hay breves, aquellas que enmiendan, como al pasar, sea alguna afirmación del soriano (110), sea la forma en que aparece consignado un nombre indígena $(41,52)$, o las que impugnan un uso léxico que se considera impropio en su aplicación (65); las hay más largas, que consisten en un mentís lapidario o en una recusación más elaborada y fundamentada (alguna vez diferida por el Inca a la propia obra, cf. 27) de las informaciones e interpretaciones de Gómara sobre aspectos sea de la lengua y costumbres del antiguo Perú (37, 38, 42, 43, 44 y luego 108 ss.), sea de la conquista y las guerras civiles $(55,63,103)$.

Ciertas citas de Gómara anunciadas por apostillas, y las apostillas mismas, nos ilustran sobre el trabajo del Inca con sus fuentes. Acerca de las modalidades de elaboración del discurso garcilasiano tenemos, en realidad, numerosas indicaciones, explícitas e implícitas, en la obra del Inca, quien pone en práctica el propósito expresado preliminarmente en los Comentarios de querer servir de "comento y glosa" a los historiadores españoles, entablando con ellos un permanente diálogo, compulsando sus obras, ratificándolas o rectificándolas allí donde fuese necesario, seleccionando de ellas versiones y citas conforme a la mayor conveniencia de su intención y de la andadura de su discurso. Pero el ejemplar apostillado de la Historia de Gómara nos abre otras mirillas a detalles interesantes sobre las formas de transvase textual. En lo que respecta a los anuncios de reproducción en discurso directo, por ejemplo, y en confirmación de lo que se puede comprobar en el examen de la obra del Inca ${ }^{32}$, se observa que el concepto de literalidad se concre-

32 Cf. J. A. Rodríguez Garrido, "Las citas de los cronistas españoles como recurso argumentativo en la Segunda parte de los Comentarios Reales", Lexis, 17 (1993), 93-114. 
ta algo laxamente en algunos casos, ya que no excluye retoques y añadidos $(15,87,106)$, o inclusive una completa reelaboración del texto de base (55).

Por lo que concierne a la selección de la cita textual, vale la pena recordar el caso de la apostilla 48, que anticipa la transcripción de un capítulo de Gómara, del cual, sin embargo, se excluyen las breves frases finales, cuyo contenido había suscitado un áspero comentario manuscrito (49), que se omite también. Este recatado criterio de lo pertinente y decoroso se observa asimismo a propósito de otras apostillas omitidas, por ejemplo la 105, que contiene una observación maliciosa y deslenguada. Por lo demás, ya en el terreno de lo no transvasado al propio texto, cabe subrayar que no todas las apostillas aparentemente anticipatorias de los correspondientes pasajes del texto del soriano se confirman luego en tal función, pues el Inca desecha estos últimos en beneficio de fragmentos de Zárate $(87,88,89)$.

Y para terminar, cabría considerar que, dentro de la diversidad de forma y función, de extensión y contenido, de las apostillas, hay algunas que sobresalen en la perspectiva de la obra garcilasiana: me refiero a las apostillas de carácter lingüístico, tanto a las más extensas y sustanciosas $(38,39)$, las cuales pasan, apenas con algunos acomodos y mejoras, a los Comentarios, cuanto a las breves, que se contraen sea a una equivalencia léxica entre palabra española y palabra indígena (28) -adelantando así la amplia práctica de la sinonimia interlingüística, ya en La Florida, y luego en los Comentarios y también en la Historia general del Perú-, sea a la rectificación de la voz indígena consignada por Gómara $(33,40,41,50,52,59)$, rectificación que, en ciertos casos, constituye el punto de partida para futuras disquisiciones semánticas y etimológicas ${ }^{33}$. En la ponderación

33 Curiosamente, hay algunos casos en los cuales Garcilaso no enmienda, como suele hacerlo, por medio de una apostilla los antropónimos indígenas consignados por Gómara, a pesar de lo cual la corrección aparece luego en la obra. Así, por ejemplo, en HPerú, lib. II, cap. 13, se refiere al capitán de Quizquiz Çoctaorco, que "los historiadores Gómara y Çárate llaman Sotaurco", y explica que el nombre quiere decir "seis cerros", por alusión al extraño lugar en que nació el personaje. Otro caso es el del capitán indígena "a quien los españoles llaman Guaipalcón” (en efecto, aparece así en Gómara y Zárate): Garcilaso corrige el nombre en Huaipallca, si bien admite que "por ser lenguaje de Quitu no sé qué signifique este nombre" (HPerú, lib. II, cap. 14). Es posible que el Inca llegase a la identificación de estos 
que hizo el Inca de una apostilla (111) de carácter parcialmente lingüístico (quizá de su informante perulero), adoptando una parte de ella y rechazando otra, podemos confirmar la importancia de esta temática y las reflexiones que le suscitaba. No hay duda, pues, por lo que se ha visto, de que ya en las apostillas a la Historia del soriano, sobre cuya fecha poco podemos decir -si bien es probable que el ejemplar de Gómara, como hemos sugerido, haya sido leído y releído, subrayado, marcado y apostillado, a lo largo de un lapso bastante prolongado, en el caso del Inca quizá superpuesto inclusive al de la composición de La Florida y las dos partes de los Comentarios- está presente la exactitud del conocimiento lingüístico como clave hermenéutica privilegiada, lo cual, por lo demás, es expresión bien conocida de la actitud humanística del Inca y de su admirable "lealtad"34 a la lengua que, según dice con tópico renacentista, había "mamado en la leche"35.

José Luis Rivarola

Università di Padova

nombres o a su etimología (como en el primer ejemplo) en un momento posterior al de la lectura de las fuentes.

${ }^{34}$ Cf. R. Cerrón-Palomino, op. cit., supra, n. 14.

35 J. Durand (op. cit., supra, n. 11) señaló que con la "redacción de los Comentarios Garcilaso cae en la cuenta que es necesario ofrecer la ortografía de los vocablos quechuas según su fonética original”. Esto es sólo parcialmente cierto, en el sentido de que en dicha obra hay mayor coherencia al respecto. Pero ya en las apostillas está presente ese "rigor lingüístico" que C. Araníbar (en el índice temático de su edición modernizada de los Comentarios, F.C.E., Lima-México, 1993, t. 2, s. v. usuta) echa de menos en ellas, por haber heredado de Porras Barrenechea el error de la transcripción "ujuta", en vez de "usuta" (cf. apostilla 28). Sobre la lengua materna puede verse mi trabajo "La lingua materna 'mamada en la leche'. Origine, interpretazione e funzione di un topos nell'Inca Garcilaso", CuN, 57 (1997), 325-344. 